Alma Mater Studiorum - Università di Bologna DEPARTMENT OF ECONOMICS

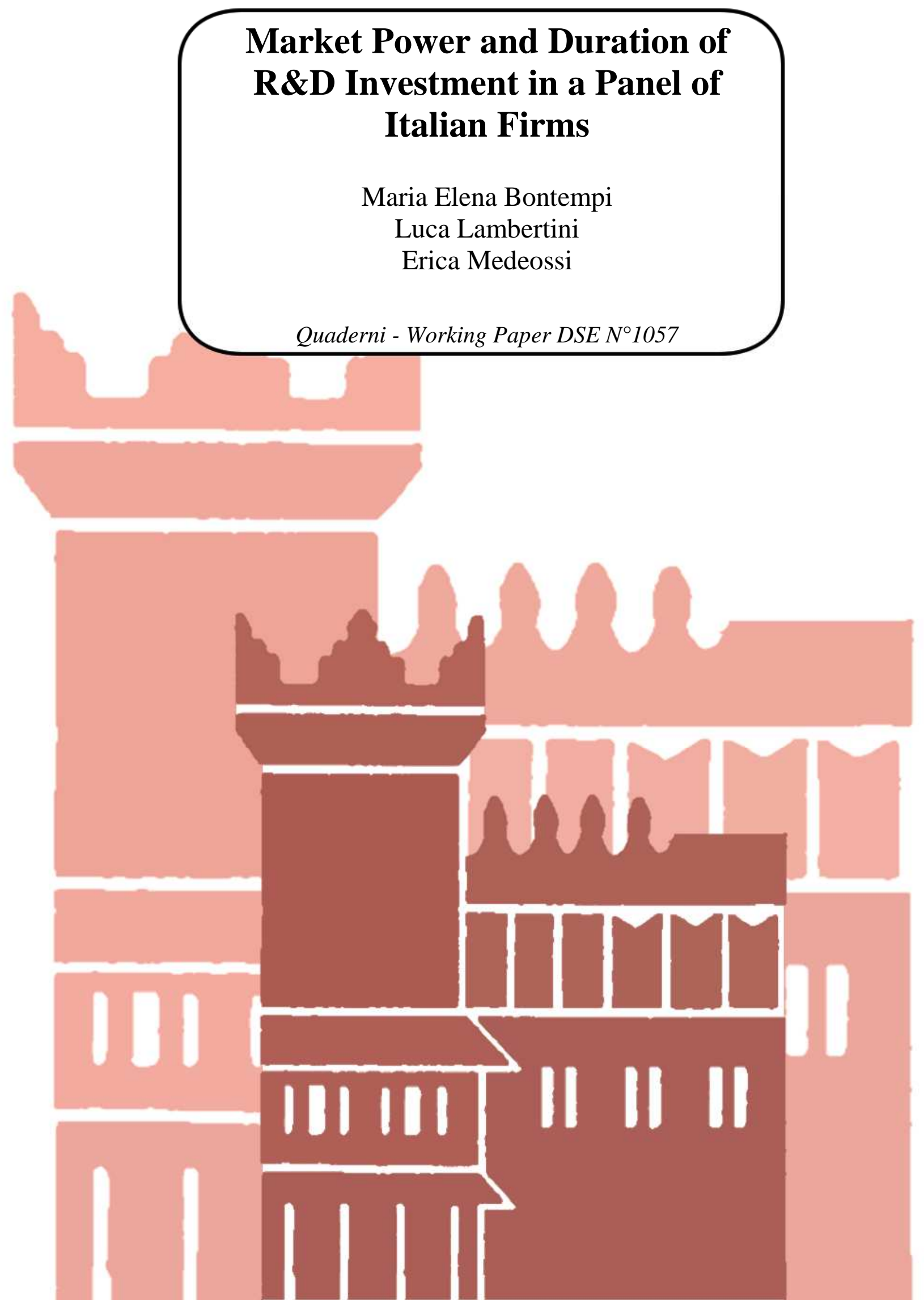




\title{
MARKET POWER AND DURATION OF R\&D INVESTMENT IN A PANEL OF ITALIAN FIRMS.
}

\author{
Maria Elena Bontempi ${ }^{[1]}$ \\ Luca Lambertini ${ }^{[2]}$ \\ Erica Medeossi ${ }^{[3]}$
}

February 19, 2016

\begin{abstract}
Studies about innovation find evidence of a positive relationship between technological advancement and firm performance, in particular when the innovative effort is continuous. This paper aims to further the analysis on the duration of R\&D investment at the firm level. The contribution of this study is threefold: first, we extend Máñez et al. [2014], Triguero et al. [2014] analysis for Spain to the Italian case: we use a panel of manufacturing and service companies, thus enlarging the view of $R \& D$ duration within the European countries. Secondly, from a methodological point of view, we employ both discrete- and continuous-time duration models, in order to test the Proportional Hazards (PH) assumption, i.e. the assumption that the hazard rate is equivalent over time across groups. Last, but not least, we assess whether a firm's likelihood of continuing investment in R\&D depends on the market power of companies. We test alternative measures for market power: the classical price-cost margin and a new proxy for the firm demand elasticity, obtained from a specific survey question. Results are in line with the hypothesis that R\&D presents considerable temporal spill overs and strong persistence, even once unobserved heterogeneity is controlled for. Also, we argue that the appropriate proxy for market power is the firm demand elasticity, and we find support for the Schumpeterian hypothesis.
\end{abstract}

Keywords: investment in R\&D, investment in physical capital, market power, duration, panel data.

JEL classification: $\mathrm{C}_{23} ; \mathrm{C}_{41} ; \mathrm{D}_{22} ; \mathrm{G}_{32} ; \mathrm{L} 10 ; \mathrm{O}_{3} 0$.

[1] Corresponding author, Dep. of Economics, University of Bologna. Email: mariaelena.bontempi@unibo.it

[2] Dep. of Economics, University of Bologna. Email: luca.lambertini@unibo.it

[3] Prometeia S.p.A., Email: erica.medeossi@prometeia.com

The authors are grateful to participants at the 5 th European Conference on Corporate R\&D and Innovation: «Industrial Research and Innovation: Evidence for Policy» (CONCORDi-2015), European Commission, Seville (1-2 October 2015). Support from Giuseppe Parigi (Bank of Italy) in providing the data as part of a joint research project on innovation and uncertainty is gratefully acknowledged. 
Given the result that innovation is a key factor for the enhancement of firms' performance, what recently seems to matter is the R\&D input persistence, which is converted into persistence of innovative output and growth of companies (Peters [2006]). This paper aims to further the discussion about what determines the persistency of R\&D investment at the firm level, taking into particular consideration the role of market power of the companies.

The result of a positive relationship between firms' innovation and performance is robust to different measures of innovation and different proxies for economic performance. Innovation is positively associated with firm growth (Audretsch [1995]) and this result is confirmed by Doms et al. [1995], who use the number of advanced technologies employed by the firm as a measure for innovation. ${ }^{1}$

Despite the difficulties embodied in a production-function framework [Bronzini and Piselli, 2006], innovation is found to be positively associated with productivity, both at the aggregated level [Bronzini and Piselli, 2006, Geroski, 1989] and at the firm level [Parisi et al., 2006]. A more comprehensive approach is carried on by Crépon et al. [1998], who move from some "stylised facts" and build an empirical model that encompasses the whole innovation process: the decision to undertake research activity, the magnitude of such effort, the output of the innovative process and the impact on firm's productivity. Innovative output is positively affected by R\&D intensity and, in turn, positively affects productivity. This approach has been widely implemented by other authors [Mairesse and Robin, 2009, Masso and Vahter, 2008, Polder et al., 2009, Van Leeuwen and Klomp, 2006].

Cefis and Ciccarelli [2005] exploit a Bayesian approach to find that the difference in profitability between innovators (defined as firms that apply for a patent) and non-innovators is greater when comparison is made between persistent innovators and persistent non-innovators. Furthermore, they find long-run persistence in profit differentials: innovators tend to converge to a higher long-run equilibrium with respect to non-innovators. Similar results are obtained by Bartoloni and Baussola [2009].

Banbury and Mitchell [1995] find that firms that are late in introducing innovations have a higher rate of exit from the market. This result is supported by the work of Cefis and Marsili [2004], who use a parametric duration model and find a positive relationship between product (process) innovation and firm survival.

What we want to shed light on, hence, are the determinants of R\&D persistence, i.e. why some firms are continuously engaged in innovation while others show intermittent investment behavior. In order to do so, we exploit a duration model approach, following the work of Máñez et al. [2014], Triguero et al. [2014], and including a large set of explanatory variables. Two determinants are particularly taken into consideration, the innovation persistence and the market power of companies.

1 This measure of innovation does not distinguish between technologies developed or just employed by the firm. Nonetheless, as shown in [Banbury and Mitchell, 1995], many firms are able to survive in the market by keeping up with the technological forefront of the industry, either by being the first to market with incremental innovation or by quickly adopting competitors' products that are successful. 
A stream of recent literature has tried to determine whether innovation persistence is "true" or spurious [Hecker and Ganter, 2014]. Spurious persistence refers to the possibility that innovation is caused by time-invariant unobserved firm characteristics that are exogenous to the sequence of innovative events, but determine its initial conditions ("past dependence" [Antonelli et al., 2012b]). Models can incorporate some correction accounting for spurious persistence, which is found to explain a significant part of the innovation process. ${ }^{2}$

Conversely, true persistence ("state dependence") results from causal effects of past activities on current innovation behaviour. In other words, it is the effect of intertemporal spill overs between subsequent innovation activities. Among the mechanisms that may explain state dependence, three major accounts can be told apart: first, technological knowledge is an economic good characterised by cumulability and non-exhaustibility, and represents at the same time an input and an output of the knowledge-generating process [Antonelli et al., 2012b]. Hence, firms that have generated new technological knowledge can rely upon such output to generate new, additional knowledge at a lower cost. Dynamic increasing returns are likely to shape innovative activities: the larger the cumulated size of innovation, the larger is the positive effect on costs ("learning-to-learn" and "learning-by-doing" effects).

A second stream, as reported in Duguet and Monjon [2004], holds that firms need to successfully profit from their innovation in order to be able to innovate again. According to this view, commercial success increases the probability of future innovation because it allows for the reallocation of profits to new research projects ("success-breads-success" effect). Firms that successfully innovate are hence more likely to follow on innovations because of higher permanent market power [Le Bas and Scellato, 2014].

Thirdly, it is worth mentioning the "sunk-costs" effect theory, according to which innovative activities are characterised by high set up costs for research facilities and the training of personnel, and by long-term commitments in terms of investment. Once research has started, the opportunity cost of interrupting it is quite high. This implies that research and development activities generate high entry and exit barriers as well [Antonelli et al., 2012a].

As pointed out in [Antonelli et al., 2012a,b, Duguet and Monjon, 2004, Le Bas and Scellato, 2014, Peters, 2006], all these arguments can be seen as complementary, rather than mutually exclusive, in explaining innovation persistence.

\section{Innovation and Market Power}

The "success-breads-success" theory is tested for by introducing market power into our set of explanatory variables. Theoretical models and empirical studies about the effects of market power on innovative activity are generally ambiguous.

Schumpeter, and the literature that sprung from his work, argues that firms with greater market power have a higher incentive to innovate because they can better appropriate the returns of their R\&D investment: intense

2 See, among others, [Antonelli et al., 2012a, Hecker and Ganter, 2014, Lhuillery, 2014, Peters, 2006, Triguero and Córcoles, 2013, Woerter, 2014]. 
market competition would imply lower post-entry rents [Hall, 2011], while low competitive pressure would reduce the risks associated with an innovative race. In fact, were the race lost, a firm would still enjoy oligopolistic profits.

On the other hand, many authors support Arrow's thesis, that competition positively affects the innovative effort, since a firm that successfully introduces a new product in the market could then become monopolist ("escape-competition effect", [Coscollá-Girona et al., 2011]). Conversely, firms that already enjoy market power do not need to innovate to stay in business. Moreover, a monopolist that innovates basically replaces itself as the monopolist in the market. This is the so called "replacement effect" put forward in [Arrow, 1962] as opposed to the "competitive effect" underlying the Schumpeterian hypothesis ([Schumpeter, 1943]). An exhaustive account of the related theoretical debate is e.g. in [Tirole, 1988], pp. 390-396. The frontier of the empirical research in this field is in [Le Bas and Scellato, 2014].

Another stream of literature (see [Geroski, 1989, Gort and Klepper, 1982]) argues its case that the problem may be more complicated. There is evidence that industries and markets evolve through different phases, and that each phase exhibits different characteristics. ${ }^{3}$ For instance, new markets show high entry and exit rates, often related to innovation races [Geroski, 1989], while consolidated markets where entry (exit) rates are near zero may be characterised by incremental innovations developed by incumbents [Banbury and Mitchell, 1995, Gort and Klepper, 1982]. There is also evidence of distinct incentives to product vs. process innovation with respect to market power Coscollá-Girona et al. [2011], Hall [2011].

The rest of this paper is organised as follows: Section 2 describes the sample, defines the variables of interest and outlines the empirical specification of the implemented models. Section 3 reports the results and discusses their interpretation. Section 4 highlights some limitations of this study and outlines a number of suggestions for further research.

\section{THE EMPIRICAL FRAMEWORK}

\subsection{The Working Sample}

Our data are obtained by merging the Survey on Industrial and Service Firms and the Company Accounts Data Service (CADS). ${ }^{4}$ All variables were drawn from the Survey, with the exception of revenues due to export and price-cost margins, that were collected from the CADS. The period of interest is 2003-2012, and contains 39,605 observations for 8,370 firms, with an average of 4 consecutive years available. Specifications that include the variables drawn from the CADS are limited to the period 2003-2010.

Due to the nature of the study, only firms that have reported positive $R \& D$ investments in at least one year are considered. The working sample consists of 3,138 firms, and has been cleaned in the usual way. 5

3 Audretsch [1991, 1995], for instance, introduces the definition of two different technological regimes, "entrepreneurial" vs. "routinised".

4 For a detailed description of the samples, see [Banca d'Italia, 2013] and http://www. centraledeibilanci.it/.

5 Dropped outliers do not influence the distributional properties of the sample, and exclude firms whose $R \& D$ investment $\geqslant 0.5$ of sales and whose demand elasticity $=0$ (see Section 2.3.1). 
Table 7 of the Appendix A shows that the working sample is still representative of firms' characteristics as they were distributed in the total sample. Some discrepancies can be found in characteristics positively (negatively) correlated with firms' R\&D investment which are over- (under-) represented in the working sample. This will be controlled for in the models.

\subsection{Measuring Duration}

As we are focusing on innovation persistence, the variable of interest is the duration of firm's innovative effort, or its "innovative spell", as in Máñez et al. [2014], Triguero et al. [2014]. Such spell is calculated for each firm in our sample as the number of years it reports positive R\&D investment. Our dependent variable is then represented by the probability that a firm interrupts $R \& D$ investment in the year $t$, given that it has invested in the period $(t-k ; t-1)$.

A distinguishing feature of duration data is that some observations may be right-censored: some spells may be incomplete and their true length unknown (this happens, for instance, when we register firms innovating in the last observed year, 2012, and we do not know whether they did the same in 2013 or not). Let $T^{\star}$ be a random variable measuring the firm's innovative spell length, and let $\mathrm{c}$ be the censoring time (i.e. the time beyond which we do not observe the firm's behaviour), measured from the time origin of the spell. Then, the random variable that will be observed is $T=\min \left(T^{\star}, c\right)$. An indicator variable $d$ is also observed, and it is equal to 1 if $T=T^{\star}, 0$ if $\mathrm{T}=\mathrm{c}$. $^{6}$

Suppose the random variable $T$ has continuous probability distribution $f(t)$, where $t$ is realisation of $T$. The cumulative probability is

$$
F(t)=\int_{0}^{t} f(s) d s=\operatorname{Pr}(T \leqslant t) .
$$

The survival function describes the probability that the innovative spell is at least of length $t$ :

$$
S(t)=1-F(t)=\operatorname{Pr}(T>t)
$$

The probability that a spell that has lasted until time $t$ will end in the next short time interval $(\Delta t)$ is given by the hazard function

$$
\begin{aligned}
\lambda(t) & =\lim _{\Delta t \rightarrow 0} \frac{\operatorname{Pr}(t \leqslant T \leqslant t+\Delta t \mid T \geqslant t)}{\Delta t}=\lim _{\Delta t \rightarrow 0} \frac{F(t+\Delta t)-F(t)}{\Delta t S(t)}= \\
& =\frac{f(t)}{S(t)}
\end{aligned}
$$

where $f(t)=d F(t) / d t$ is the density function. Roughly speaking, $\lambda(t)$ is the rate at which spells will be completed at duration $t$, given that they last until $t$ [Greene, 2005].

Table 1 reports the functions of survival and hazard, estimated by the Kaplan-Meyer and the Nelson-Aalen estimators respectively. The survival function is less-than-proportionally decreasing in time: at the end of the considered period, only about $23 \%$ of firms are still spending in $R \& D$, but most of exits take place at the very beginning, with $50 \%$ of firms ceasing

6 It is crucial to assume that firms whose spells are censored at time $\mathrm{c}$ are representative of firms whose spell length is $T \leqslant c$. Thus, $c$ must be independent of $T^{\star}$, having taken account of other factors (explanatory variables) [Kiefer, 1988]. 
investment within the first 3 years. On average, firms invest for more than 3 consecutive years ( 3.06 years). ${ }^{7}$

\subsubsection{Dealing with Left-Censoring}

Left censoring occurs when we do not observe the starting date of the innovative spell (e.g. this concerns the spells of firms reporting positive R\&D investment in the first year, 2003, since we do not have data about innovation prior to 2003 and are therefore unable to determine when innovation began). ${ }^{8}$

As pointed out in [Iceland, 1997], omitting left-censored cases could lead to serious selection bias since one might exclude from the analysis firms that present the longest innovative spells. In fact, while firms that invest in R\&D discontinuously (i.e. have several short spells) may be expected to re-enter the data set, firms that continuously engage in innovative activity would be ignored, leading to a downward bias in estimation of the survival function. Bias is increasing in the share of left-censored spells and in the correlation between explanatory variables and the error term. ${ }^{9}$

Several methods can mitigate the problem, but to our knowledge there is no solution. ${ }^{10}$ Stevens [1995] suggests, as implemented in [Triguero et al., 2014], to include left-censored spells in the analysis and add a dummy variable indicating whether the observed spell is left-censored or not. For tractability reasons we will follow this approach, that allows the retaining of all available information, although it does not represent a solution to bias and selectivity.

\subsection{Explanatory Variables}

Explanatory variables are:

- The logarithm of innovative stock (ln RD), contemporary and lagged values; ${ }^{11}$

- The number of spells in which the firm has continuously invested in R\&D (Spell Number);

- The elapsed duration of each spell (Time);

7 These estimators are more accurate for short spells, since inference about very long durations is based on fewer observations [Kiefer, 1988].

8 Innovative spells are likely to be left-truncated too, since firms might have experienced innovative spells that ended before 2003. Hence, the analysis is conditional upon firm survival up to 2003 , and firm engaging in R\&D investment in 2003 or later (delayed-entry). Fortunately, as shown by Bhattacharjee et al. [2002], Jenkins [2005], delayed-entry does not jeopardise estimation as long as the correct entry time is considered (which is, the first year a firm reports positive R\&D investment, i.e. it becomes at risk of discontinuing innovative activity).

9 Carter and Signorino [2013] report that the bias is severe if $10 \%$ or more observations are left-censored. It is hence a serious issue for our sample, in which over $50 \%$ of spells are leftcensored.

10 For a review, see the discussion on StataList: http://www.stata.com/statalist/archive/ 2009- 09/msg00081.html, and [Carter and Signorino, 2013, Iceland, 1997, Stevens, 1995].

11 This stock measure is computed by the means of the permanent inventory method: given the flow measure $I_{t}^{R \& D}$

$$
R D_{t}=I_{t}^{R \& D}+(1-\delta) R D_{t-1} \text {. with } \delta \text { representing the depreciation rate. }
$$

The literature usually finds a high depreciation rate for knowledge (over 30\%) [Bublitz and Ettredge, 1989, Hirschey, 1982]. This is because innovation has an incremental nature and also because knowledge tends to leak to competitors, due to both expired patent rights and operations of reverse engineering [Griliches, 1998]. A discussion on R\&D for the Italian case is in [Bontempi and Mairesse, 2015]. 
Table 1: Spell Description; Survival and Hazard Functions.

\begin{tabular}{|c|c|c|c|c|}
\hline & \multicolumn{2}{|c|}{ All Spells } & \multicolumn{2}{|c|}{ No left-censoring ${ }^{\dagger}$} \\
\hline & Survival & Hazard & Survival & Hazard \\
\hline 1 & 0.7303 & 0.0079 & 0.7035 & 0.0115 \\
\hline 2 & 0.5910 & 0.0097 & 0.5598 & 0.0141 \\
\hline 3 & 0.5037 & 0.0104 & 0.4575 & 0.0148 \\
\hline 4 & 0.4207 & 0.0106 & 0.3692 & 0.0152 \\
\hline 5 & $0.355^{8}$ & 0.0106 & 0.3106 & 0.0152 \\
\hline 6 & 0.3031 & 0.0103 & 0.2757 & 0.0151 \\
\hline 7 & 0.2645 & 0.0100 & 0.2498 & 0.0152 \\
\hline 8 & 0.2398 & 0.0098 & 0.2299 & 0.0157 \\
\hline $9^{\ddagger}$ & 0.2219 & 0.0097 & 0.2299 & 0.0157 \\
\hline $10^{\ddagger}$ & 0.2219 & 0.0097 & - & 一 \\
\hline Num. of Spells & \multicolumn{2}{|c|}{3,939} & \multicolumn{2}{|c|}{1,910} \\
\hline Avg. Num. of Spells by Firm & \multicolumn{2}{|c|}{1.2557} & \multicolumn{2}{|c|}{1.220} \\
\hline Avg. Spell Duration & \multicolumn{2}{|c|}{3.0567} & \multicolumn{2}{|c|}{2.5073} \\
\hline Num. of Firms & \multicolumn{2}{|c|}{3,137} & \multicolumn{2}{|c|}{1,565} \\
\hline Time at Risk & \multicolumn{2}{|c|}{9,589} & \multicolumn{2}{|c|}{3,924} \\
\hline
\end{tabular}

$(\dagger)$ The elimination of left-truncated records from the data set means the dismissal of all spells observed in 2003.

( $\ddagger$ ) At the end of 2012 we observe zero failures (i.e. interruption of R\&D investment). Hence, estimates of survival and hazard in year 1o (9) are equal to those in year 9 (8).

- A dummy equal to 1 if the spell is left-censored (Left Cens., see previous Section 2.2.1);

- Planned investments in physical and software capital over sales (IM and IS, respectively);

- The difference between planned physical and software investments in $t-1$, and the effective investment in $t(\Delta I M$ and $\Delta I S$, respectively);

- Cash flow net of dividends paid over sales (CF), contemporary and lagged values;

- Short- and long-term bank debt and financial debt versus other financial institutions over sales (D), contemporary and lagged values;

- A dummy equal to 1 if the ratio of revenues from export to total revenues is positive (Exp);

- A dummy variable equal to 1 if the firm belongs to a High-Tech industrial sector (HTech);

- Market power: we compare two measures, the price-cost margin (PCM) and the firm-level demand elasticity $(-\eta)$, discussed in the following Section 2.3.1);

- The Bloom Index of Economic Policy Uncertainty (Bloom, [Baker et al., 2013]);

- Control variables for firm's age, size (log of the number of employees), group-membership, type of ownership, geographical area (variables ln Age, ln Size, Group, Family, Centre, South).

\subsubsection{Demand Elasticity}

Measuring market power is a non-trivial issue, since researchers usually are not able to observe demand elasticity or marginal costs. Hence, the most used proxies in the empirical industrial organisation literature are concentration measures (concentration ratios, Hirshman-Herfindal indexes, market 
shares) or PCMs. ${ }^{12}$ These measures are widely used in spite of their drawbacks. As reported in [Coscollá-Girona et al., 2011, Domowitz et al., 1986], high degrees of concentration, or increased PCMs, are not necessarily symptoms of lack of competition. Boone [2000] points out that there is no simple relationship between product market competition and market structure if firm's cost efficiency levels are asymmetric. For instance, enhanced competition may raise the market shares of the most efficient firms at the expense of inefficient ones, increasing the Herfindal index ("reallocation effect", [Boone, 2008]); or concentration may rise as the most inefficient firms exit the market because of more intense competition ("selection effect", [Boone, 2008]). The latter case may also lead to an increase in the average PCM. In like manner, if less competitive pressure leads to higher costs due to inefficiency or absence of cost-reducing innovations, the PCM will decrease [Coscollá-Girona et al., 2011]. Furthermore, as pointed out by Domowitz et al. [1986], PCMs are sensitive to demand fluctuations.

In this paper we first follow the standard way of measuring market power as the price-cost margin, defined by (see [Bontempi et al., 2010, Domowitz et al., 1986]:

$$
\mathrm{PCM}=\frac{\text { Sales }+\Delta \text { Inventories }- \text { Payroll }- \text { Materials }}{\text { Sales }} .
$$

Secondly, an important contribution of this study is the use of an alternative measure of market power, given by the implied demand elasticity, obtained from qualitative data. In the 1996 and 2007 surveys firms were asked the following question:

Consider the following hypothetical experiment: suppose your firm raises today the price of the goods produced by to percent. What would be the percent change in the value of sales, assuming that your firm's competitors leave their prices unchanged, and holding everything else constant? ${ }^{13}$

Such a question directly refers to the firm price elasticity of demand; following Guiso et al. [2006], let $z \in(-100,100]$ be the answer to the question, and the elasticity is computed as:

$$
-\eta=\frac{z}{100}-1
$$

The mean value is -1.38 , and the great majority of firms show an implied elasticity greater than 1 in absolute value. Descriptive statistics given in Table 2 are consistent with some firms having market power.

Among surveyed firms, only 179 responded to both the questionnaires in which the question was submitted. Little difference can be found in their answers, and it is probably due to rounding figures rather than significant changes in the elasticity. In fact, while the overall distribution is quite similar across years, the frequency of round figures rises in 2007. Hence, the mean value of the implied elasticity has been used for such firms, as this operation

12 For innovation studies that employ concentration measures see, among others, [Acs and Audretsch, 1988, Audretsch, 1991, Banbury and Mitchell, 1995, Blundell et al., 1999, Cefis and Ciccarelli, 2005, Duguet and Monjon, 2004, Geroski et al., 2007, Lhuillery, 2014, López-García and Puente, 2006, Máñez et al., 2014]; for studies that employ the PCM see [Aghion et al., 2002, Antonelli et al., 2012b, Audretsch, 1995, Greenhalgh and Rogers, 2006]; Woerter [2014] uses the number of each firm's principal competitors.

13 [Banca d'Italia, 2008]. 
does not change the statistical properties of the distribution, as shown in Table 2.

Table 2: Implied Elasticity.

\begin{tabular}{lrrrrrrrrr}
\hline Variable & Mean & Min & 25th P. & 50th P. & 75th P. & Max & Std. Dev. & Skew. & Kurt. \\
\hline$-\eta$ & -1.38 & -2.00 & -1.60 & -1.30 & -1.10 & -0.10 & 0.36 & -0.40 & 2.34 \\
Avg. $-\eta$ & -1.38 & -2.00 & -1.60 & -1.30 & -1.10 & -0.10 & 0.35 & -0.44 & 2.44 \\
\hline
\end{tabular}

The fact that for some firms $|\eta|<1$ means that the Lerner index is not constrained to 1 . This is in contrast with the hypothesis of firms maximising their profits, since some of them seem to be operating in the inelastic portion of the demand curve. In other words, if increasing their selling prices would grant an increase in sales, why would they not do so? Quite simply, this "irrational" behaviour can be explained by the fact that firms are not in their long-run equilibrium. Furthermore, a closer look at the 179 firms for which $z$ is observed in two points in time confirms this explanation: $27(15 \%)$ out of 179 firms operate in the unelastic portion of the demand curve in either 1996 or 2007, 10 move from the unelastic to the elastic portion, 17 the other way around. All other firms register $|\eta| \geqslant 1$ in both periods.

Table 3 reports some descriptive statistics about the relationship between the implied demand elasticity, the PCM, firm's age, and firm's size.

Table 3: R\&D, PCM and Size across Elasticity Classes.

\begin{tabular}{lrrr|rrr|rrrr}
\hline \multirow{2}{*}{$\eta$ Class } & \multicolumn{3}{c}{$\mathrm{I}_{\mathrm{t}}^{\mathrm{R} \& \mathrm{D}}$} & \multicolumn{3}{c}{ PCM } & \multicolumn{3}{c}{ Size } \\
\cline { 2 - 10 } & Mean & 5 oth P. & $\mathrm{N}$ & Mean & 50 P. & $\mathrm{N}$ & Mean & 50 P. & $\mathrm{N}$ \\
\hline Highly El. & 0.006 & 0.000 & 4,182 & 0.078 & 0.080 & 4,601 & 629 & 175 & 8,749 \\
Elastic & 0.007 & 0.000 & 5,080 & 0.092 & 0.088 & 6,571 & 514 & 190 & 12,060 \\
Unitarily El. & 0.014 & 0.000 & 407 & 0.066 & 0.092 & 379 & 397 & 110 & 855 \\
Inelastic & 0.007 & 0.000 & 1,277 & 0.109 & 0.103 & 969 & 625 & 215 & 2,192 \\
\hline Total & 0.007 & 0.000 & 10,946 & 0.087 & 0.086 & 12,520 & 563 & 183 & 23,856 \\
\hline
\end{tabular}

Note: Computed elasticity has been split into the following categories: (1) Highly elastic if $|\eta|>1.5$, (2) Elastic if $1.5>|\eta|>1$, (3) Unitarily elastic if $|\eta|=1,(4)$ Inelastic if $|\eta|<1$.

\subsection{Empirical Specification}

\subsubsection{The Cox Model}

As in Máñez et al. [2014], we use the semi-parametric Cox model as starting point for our analysis, since it is quite flexible and does not require any assumption about the functional form of the hazard.

Each $i$-th firm faces a hazard function which is common to all firms (the "baseline" hazard, $\lambda_{0}$ ) and is then modified by the set of explanatory variables $x_{i}^{\prime}$. The relationship between the individual risk and the vector $x_{i}^{\prime}$ depends upon the estimated coefficient vector $\beta$. The Cox model assumes the individual risk to be equal to the product of the "baseline" risk and the function $\phi\left(x_{\mathfrak{i}}^{\prime}, \beta\right)=\exp \left(x^{\prime} \beta\right)$ :

$$
\lambda_{i}(t)=\lambda_{0}(t) \phi\left(x_{i}^{\prime} \beta\right)=\lambda_{0}(t) \exp \left(x_{i}^{\prime} \beta\right) .
$$

In other words, the shape of the hazard function is the same for all firms, and variations in $x_{i}^{\prime}$ just shift the function. This allows for a direct interpretation of the estimated coefficients, since

$$
\beta=\frac{\partial \ln \phi(x, \beta)}{\partial x}
$$


represents the constant proportional effect of an increase in the relative variable on the conditional probability of exiting the innovative state. This approach provides estimation of $\beta$ without requiring estimation of $\lambda_{0}$.

The Cox model suffers from four potential drawbacks:

1. It implies a continuous time specification (hence it assumes no ties). If ties rarely occur, it is possible to account for them with the Efron method. ${ }^{14}$ When ties are frequent, there is no way to avoid asymptotic bias in both the estimated coefficients and the correspondent covariance matrix [Hess and Persson, 2010];

2. Unobserved heterogeneity (i.e. spurious persistence) cannot be included;

3. It is not possible to obtain any information about the shape of the hazard function $\lambda_{0}$, which is actually important in order to ascertain if there is negative (positive) duration dependence. A distribution the hazard function of which slopes downward (upward) is said to have negative (positive) duration dependence Kiefer [1988], Lancaster [1979], Verbeek [2004].

4. The Cox model in Equation (5) assumes Proportional Hazards (PH). This means that the effect of any explanatory variable on the hazard is assumed to be constant over duration time. It is straightforward that, should the PH assumption fail, estimated covariate effects would be biased. The PH assumption may fail to hold for two reasons: (1) because the effect of explanatory variables is intrinsically non-proportional; (2) because unobserved individual heterogeneity is not accounted for and makes the effect depend on duration time, even if the underlying process is of the proportional hazards form [Brenton et al., 2009]. Following Hess and Persson [2010], we have performed a test based on the Schoenfeld residuals. Results are reported in Table 4, and strongly reject the $\mathrm{PH}$ assumption.

\subsubsection{The Cloglog Model}

The Cloglog model assumes a complementary log-logistic form for the hazard, and overcomes many limitations that affect the Cox model. In fact, as well as giving a discrete time representation of an underlying continuous time proportional hazards model, it also controls for unobserved heterogeneity and gives information about the duration dependence of the hazard. Hazard and survival functions are given by:

$$
\begin{aligned}
& \lambda(t)=\frac{\lambda p(\lambda t)^{p-1}}{1+(\lambda t)^{p}} ; \\
& S(t)=\frac{1}{1+(\lambda t)^{p}} ;
\end{aligned}
$$

where the $\log$ of duration, $\ln t$, has a logistic distribution with mean $-\ln \lambda$ and variance $\pi^{2} /\left(3 p^{3}\right)$, ( $\lambda$ and $p$ are unknown parameters to be estimated). When $p \leqslant 1$, the hazard rate is monotonically decreasing to zero as $t$ increases. If $p>1$, the hazard increases at first and then decreases to zero [Wooldridge, 2002].

14 For details, see StataCorp. [2013]. 
Table 4: Test of Proportional Hazard Assumptions for the Cox Model.

\begin{tabular}{|c|c|c|c|c|c|c|c|}
\hline \multirow[t]{2}{*}{ Variables } & \multicolumn{7}{|c|}{$\begin{array}{c}\text { Cox Models, as in Table } 8 \\
\text { P-value for the Test of Schoenfeld Residuals. }\end{array}$} \\
\hline & (1) & $(2)$ & (3) & (4) & (5) & (6) & (7) \\
\hline $\ln R D_{t}$ & (0.0000) & (o.00oo) & $(0.4018)$ & (0.0000) & (0.0000) & & \\
\hline $\ln R D_{t-1}$ & & & & & & (0.0000) & (o.0000) \\
\hline Spell Number & (0.0000) & (o.oooo) & (0.000o) & (0.0000) & (0.0000) & (0.000o) & (0.0000) \\
\hline Time & (0.0000) & (0.000o) & (0.000o) & (0.0000) & (0.000o) & (0.000o) & (0.0000) \\
\hline Left Cens. & (0.0000) & (0.0005) & $(0.9623)$ & (0.0163) & $(0.9314)$ & (0.0123) & (o.8744) \\
\hline $\mathrm{I} M_{t}$ & (0.1154) & $(0.5954)$ & $(0.6278)$ & & & $(0.3637)$ & \\
\hline$\Delta \mathrm{IM}$ & & & & (0.0000) & (0.0000) & (0.0000) & $(0.0000)$ \\
\hline $\mathrm{IS}_{\mathrm{t}}$ & (0.0069) & (0.0235) & (o.1616) & & & $(0.3628)$ & \\
\hline$\Delta \mathrm{IS}$ & & & & (o.1989) & $(0.8150)$ & (0.0000) & (0.0023) \\
\hline$C F_{t}$ & $(0.6589)$ & $(0.0542)$ & $\left(0.815^{8}\right)$ & (0.4547) & (0.0112) & & \\
\hline $\mathrm{CF}_{\mathrm{t}-1}$ & & & & & & (0.0924) & (0.0004) \\
\hline $\mathrm{D}_{\mathrm{t}}$ & $(0.2104)$ & (0.0001) & $(0.1560)$ & (0.0000) & (0.0001) & & \\
\hline$D_{t-1}$ & & & & & & $(0.3074)$ & (0.1133) \\
\hline Exp & (0.0074) & (0.0105) & (0.2255) & (0.0082) & $(0.0958)$ & (0.0087) & (0.0127) \\
\hline HTech & (0.7329) & (0.1318) & $(0.9844)$ & (0.2097) & $(0.4111)$ & (0.1333) & (o.1347) \\
\hline$-\eta$ & & $\left(0.675^{8}\right)$ & (o.8o88) & $(0.5136)$ & (0.9077) & (0.9945) & (o.8186) \\
\hline$P C M$ & $(0.3043)$ & & & & & & \\
\hline Bloom & & & 0.0000 & & 0.0000 & & 0.0000 \\
\hline ln Age & $(0.5822)$ & (o.4899) & (o.3338) & (o.80og) & (0.4375) & (0.9742) & (0.2949) \\
\hline ln Size & (0.9349) & $(0.2604)$ & (o.6935) & (0.0224) & (0.3228) & (0.0053) & (o.0095) \\
\hline Group & (0.906o) & (0.1607) & (o.3379) & (0.7461) & $(0.3384)$ & (o.8780) & (o.8319) \\
\hline Family & (0.0000) & (0.0113) & (0.0058) & (0.0414) & (0.0015) & (0.0945) & (0.0022) \\
\hline Centre & (0.000o) & (0.000o) & (0.0158) & (0.0000) & (0.000o) & (0.0000) & (0.0000) \\
\hline South & (0.0000) & (0.0000) & (0.0003) & (0.0000) & (0.0000) & (0.0000) & (0.0000) \\
\hline Global Test & (0.0000) & (o.oooo) & (o.00oo) & (0.0000) & (0.0000) & (0.0000) & (o.0000) \\
\hline
\end{tabular}

The log-likelihood is

$$
\log L=\sum_{i=1}^{n} d_{i} \ln \left(\frac{\lambda_{i t}}{1-\lambda_{i t}}\right)+\sum_{i=1}^{n} \sum_{k=1}^{t} \ln \left(1-\lambda_{i k}\right) ;
$$

where $d_{i}=1$ if the interval is right-censored and 0 otherwise. Máñez et al. [2014] report that Equation (9) can be rewritten as the log-likelihood function of a binary dependent variable $y_{i k}=1$ if spell $i$ ends in year $k$, and 0 otherwise:

$$
\log L=\sum_{i=1}^{n} \sum_{k=1}^{t}\left[y_{i k} \ln \lambda_{i k}+\left(1-y_{i k}\right) \ln \left(1-\lambda_{i k}\right)\right] ;
$$

where $\lambda$ is

$$
\lambda_{t}\left(x_{i t}^{\prime} \beta\right)=1-\exp \left[-\exp \left(\beta_{0}+x_{i t}^{\prime} \beta+\gamma_{t}\right)\right] ;
$$

where $x_{i t}$ are time-varying covariates (constant within the interval), and $\gamma$ is a polynomial in time that allows for a flexible definition of duration dependence. In the present work, the highest order polynomial that resulted significant was the first.

As discussed in Section 1, many studies highlight the importance of unobserved heterogeneity (let denote it by $v_{\mathfrak{i}}$ ) in explaining the persistence of innovation. If unobserved heterogeneity is indeed important, ignoring it will lead to over- (under-) estimation of the degree of negative (positive) duration dependence [Jenkins, 2005, Lancaster, 1979]. This is a selection effect: if duration dependence is negative, observation with high values of $v$ will fail faster, ceteris paribus. Furthermore, the proportionate effect $\beta_{k}$ of a given regressor $x_{k}$ on the hazard rate will no longer be constant and independent of survival time, and $\beta_{k}$ will be downward-biased [Lancaster, 1979]. 
Heterogeneity enters the underlying continuous hazard function multiplicatively:

$$
\lambda\left(t, x_{i t}\right)=\lambda_{0}(t) \exp \left(\beta_{0}+x_{i t}^{\prime} \beta\right) v_{i},
$$

hence, the Cloglog model becomes:

$$
\lambda_{t}\left(x_{i t}\right)=1-\exp \left[-\exp \left(\beta_{0}+x_{i t}^{\prime} \beta+\gamma_{t}+u_{i}\right)\right],
$$

where $u_{i} \equiv \ln v_{i}$ and $v_{i}$ is a random variable taking on positive values, with mean normalised to one and finite variance $\sigma^{2}$. It is crucial to assume that $v_{i}$ is distributed independently of $x_{i t}$ and $t$. This variable can be interpreted as the impact of omitted (unobserved) variables, or of measurement errors in recorded regressors or recorded survival times [Jenkins, 2005]. Estimation of this model requires an expression for the density function that does not condition upon the unobserved effects. It is hence convenient to specify a distribution for $v$ in order to "integrate out" the unobserved effect (i.e. one works with the function $\lambda\left(t, x^{\prime} \mid \beta, \sigma^{2}\right)$ rather than $\left.\lambda\left(t, x^{\prime} \mid \beta, v\right)\right)$. For tractability reasons, the choice of distribution is limited to those that provide a closed form expression for the frailty hazard function.

The Stata command $x t c \log \log$ allows for the estimation of the model assuming the heterogeneity $v_{i}$ is normally distributed; the program pgmhaz 8 has been used for Gamma-distributed frailty.

The Cloglog framework also allows for the incorporation of unobserved heterogeneity non-parametrically by assuming that there are several types of firm spell ("mass points"). This implies that each spell has probabilities associated with the different mass point, allowing for different intercepts of the hazard function. For a model with $n$ mass points, the hazard in Equation (13) becomes:

$$
\lambda_{t, m}\left(x_{i t}\right)=1-\exp \left[-\exp \left(m_{n}+\beta_{0}+x_{i t}^{\prime}+\gamma_{t}\right)\right] .
$$

Normalising the first mass point to zero, the intercept for type- 1 firm is $\beta_{0}$, that for type-2 firm is $\beta_{0}+m_{2}$ and so on. Regressions that incorporate non-parametric frailty were run with the Stata program hshaz.

In order to verify the PH assumption in the Cloglog model, we follow Hess and Persson [2010], allowing the explanatory variables to vary over time in the Cloglog model with unobserved heterogeneity. Testing the $\mathrm{PH}$ assumption reduces here to the verification of the hypothesis $\xi_{k}=0, \forall \mathrm{k}=$ $1, \ldots, K$, where $\xi_{k}$ is the coefficient of the interaction term $\left(x_{k} \cdot t\right)$. Results for this test are provided in Table 5. The $\mathrm{PH}$ assumption holds throughout all specifications, hence the Cloglog model is appropriate for the phenomenon description.

\subsubsection{The Probit Model}

Discrete-time survival analysis often employs Logit models as an alternative to semi-parametrical approaches as the Cloglog, in order to relax the $\mathrm{PH}$ assumption. However, since the considered event (interruption of innovative effort) occurs quite frequently, and many spells last longer than 1 year, the Logit assumption of event independence would be invalid, leading to biased estimates [Banbury and Mitchell, 1995]. Hence, we prefer to use a dynamic random-effects Probit model, following [Antonelli et al., 2012a, Hecker and Ganter, 2014, Lhuillery, 2014, Peters, 2006, Triguero and Córcoles, 2013, Triguero et al., 2014]. 
Table 5: Test of Proportional Hazard Assumptions for the Cloglog model.

\begin{tabular}{|c|c|c|c|c|c|c|c|}
\hline \multirow[t]{2}{*}{ Variables } & \multicolumn{7}{|c|}{$\begin{array}{l}\text { Cloglog models, as in Table } 9 \\
\text { P-value for the Hypothesis } \xi_{k}=0 \text {. }\end{array}$} \\
\hline & (1) & (2) & (3) & (4) & (5) & (6) & (7) \\
\hline $\ln R_{t}$ & (0.5327) & (0.4102) & (0.9336) & (0.3598) & $(0.7211)$ & & \\
\hline $\ln R D_{t-1}$ & & & & & & (o.0355) & (0.0399) \\
\hline Spell Number & (o.8247) & (0.6805) & (0.7939) & $(0.5110)$ & (o.6904) & (o.3155) & $(0.3645)$ \\
\hline $\mathrm{I} M$ & (0.1871) & $(0.3145)$ & $(0.4566)$ & & & & \\
\hline$\Delta \mathrm{IM}$ & & & & (0.6744) & (0.5601) & (o.6878) & (0.7204) \\
\hline IS & (0.5155) & (0.7277) & (0.7484) & & & & \\
\hline$\Delta \mathrm{IS}$ & & & & (o.8338) & (o.8177) & (0.1130) & (0.3997) \\
\hline $\begin{array}{l}C F_{t} \\
C F_{t-1}\end{array}$ & (0.8126) & (0.7012) & (0.8828) & (0.8663) & (0.9877) & $(0775)$ & $(0.7,8)$ \\
\hline & (0.0517) & $(0.4906)$ & $(0.5566)$ & (0.6681) & (0.6908) & $(0.14 / 3)$ & $(0.1040)$ \\
\hline$D_{t-1}$ & & & & & & (o.o686) & (0.1112) \\
\hline$-\eta$ & & (0.3011) & $(0.3327)$ & $(0.3860)$ & $(0.4118)$ & $(0.5165)$ & $(0.5204)$ \\
\hline PCM & (o.8250) & & & & & & \\
\hline Bloom & & & (0.2237) & & $(0.4221)$ & & (0.1382) \\
\hline ln Size & (o.6420) & (0.1894) & (0.1023) & (o.6119) & (0.3894) & (0.9500) & (o.8544) \\
\hline ln Age & (o.6566) & (o.6835) & $(0.8342)$ & $(0.4868)$ & $(0.5283)$ & $(0.6216)$ & (o.6811) \\
\hline Global Test & (o.6776) & (o.6672) & $(0.7650)$ & (o.9479) & (o.9568) & (o.1385) & (0.1638) \\
\hline
\end{tabular}

Hess and Persson [2010] report that this test is robust to the assumed distribution of heterogeneity (here we use normally-distributed frailty).

The expressions in the likelihood function are given by

$$
\begin{aligned}
f\left(y_{i t} \mid x_{i t}, \alpha_{i}, \beta\right) & =\Phi\left(\frac{x_{i t}^{\prime} \beta+\alpha_{i}}{\sqrt{1-\sigma_{\alpha}^{2}}}\right) & & \text { if } y_{i t}=1, \\
& =1-\Phi\left(\frac{x_{i t}^{\prime} \beta+\alpha_{i}}{\sqrt{1-\sigma_{\alpha}^{2}}}\right) & & \text { if } y_{i t}=0,
\end{aligned}
$$

where $\Phi$ denotes the cumulative density function of the standard normal distribution. Unobserved heterogeneity is assumed to be normally distributed (Stata command xtprobit).

\section{RESULTS}

Estimation results are shown in Table 6. Three specifications are reported for each model: columns (1) contain the "traditional" approach that uses the PCM to proxy for market power; columns (3), (7) use the implied elasticity $-\eta$. Furthermore, columns (7) use the explanatory variables' lags in order to control for simultaneity problems [Coscollá-Girona et al., 2011]. We consider column (7) in the Cloglog framework with "mass points" as the most reliable empirical specification for our data, the other estimates being reported as robustness checks. Our general results are discussed in what follows.

CUMULATIVENESS OF R\&D. The (true) persistence of the innovation process is accounted for by the logarithm of the R\&D stock and by the variables Spell Number, Time. This set of variables captures the phenomena of cumulativeness, irreversibility and increasing returns of the innovative investment, learning-by-doing and learning-to-learn effects. Overall, there is strong evidence of persistence in R\&D investment: the coefficient for the accumulated knowledge stock is negative and significant, also when its lagged value is used. ${ }^{15}$ The coefficient of Time is also negative (although sometimes nonsignificant), suggesting that the longer a firm has continuously invested in

15 In columns (1d), (7d) coefficients are non-significant, but p-values are close to $10 \%$. 
$R \& D$, the more likely it is that it will keep investing (negative duration dependence). This is coherent with our expectations, and confirms the results of Acs et al. [2008], Hecker and Ganter [2014], Máñez et al. [2014], Triguero et al. [2014], who find significant temporal spill overs of R\&D. As for the number of previous spells, the coefficient is never significant (and negative). Given the short time-window of the analysis, it can be inferred that firms that have shown a discontinue attitude towards innovation, but have had several innovative spells are less likely to interrupt investment again.

LEFT-CENSORING. Left-censored spells have been included in the analysis, and the dummy variable Left-Cens. is negatively associated with firms discontinuing their innovative activity, as in Máñez et al. [2014], Triguero et al. [2014]. As discussed in Section 2.2.1, this precaution just mitigates (rather than correct) the bias in estimation due to left-censoring. Nevertheless, the negative and significant coefficient confirms the preliminary hypothesis that left-censored spells are likely to be the longest. The exclusion of such spells would have hence resulted in a severe overestimation of the hazard function.

PHYSICAL AND SOFTWARE INVESTMENT. Although rarely significant, variables that take into account firms' planned investment in physical capital (machinery, IM) and software (IS) give some information about the relationship between different types of investment. While IM always has a positive coefficient, hinting at some sort of substitution effect with respect to R\&D expenditures, software investment's negative coefficient may suggest a complementarity between innovative activities and the acquisition of information technology, as found by Polder et al. [2009].

Alternatively to the planned expenditures, we have used as explanatory variables the difference between the planned investment in $t-1$ and the effective investment in $t, \Delta I M, \Delta I S$. Guiso et al. [2006] show that planned investment in usually quite accurate, since deviating from plans is costly. Hence, $\Delta \mathrm{IM}, \Delta \mathrm{IS}$ represent a variation in investment level due to some unexpected cause. The physical capital variation's coefficient is ambiguous in sign, that of software is always negative, and both are non-significant, suggesting that the likelihood of spending in R\&D is relatively unaffected by unanticipated deviations from investment plans. This is in line with the result obtained for the variable Bloom, that controls for uncertainty and will be discussed below. Of course, there could be variations in the magnitude of the innovative effort, which are not caught by our model's specification.

FINANCES. Máñez et al. [2014] find that the firm's cash flow has a negative and significant effect on the likelihood of interrupting R\&D investment, supporting the hypothesis that firms that have internal funds available can better sustain the expenses connected with research and development activities. Among studies that use duration models, few include a direct measure of debt (Triguero and Córcoles [2013] use firm's leverage, defined as external funds over equity). We think it is quite important that the two sources of funds were included, either from the point of view of the correct specification of the capital structure behind the model of R\&D duration (Bontempi [2003]), either for the institutional characteristics of the country under analysis (Munari et al. [2010]). Italy's national corporate governance is classified as "insider-dominated" and the corporate financial system as "continental". Such characteristics entail lower protection of external investors (with respect to "outsider-dominated" systems as the UK and the US), strong and 
stable firm-bank liaisons, and lower occurrence of changes in corporate control. Even if rarely significant, overall the negative sign of cash flow $(C F)$ and the positive one for debt $(D)$ tend to signal the presence of liquidity constraints due to agency costs and asymmetric information particularly relevant if the R\&D case (see also Bontempi [2016]).

international competition. The dummy variable Export controls for firm's exposure to international competition (unfortunately, data about import - i.e. the penetration of international competition - were not available). The coefficient is negative and, sometimes, significant. ${ }^{16}$ The literature ([Antonelli et al., 2012b, Coscollá-Girona et al., 2011, Hecker and Ganter, 2014, Máñez et al., 2014, Masso and Vahter, 2008, Peters, 2006, Triguero and Córcoles, 2013]) finds a positive and strong relationship between export and R\&D continuity. Lööf et al. [2015] point out that the openness of business sectors increases the likelihood that a firm will access a larger amount of information, exploit spill overs, and thus increase its knowledge stock ("learning-by-exporting" effect). We do not find conclusive evidence of the sort, coefficients being negative but only rarely significant.

technological opportunities. Contrary to the findings of CoscolláGirona et al. [2011], Crépon et al. [1998], Duguet and Monjon [2004], Hecker and Ganter [2014], Huang [2008], Máñez et al. [2014], Peters [2006], Triguero and Córcoles [2013], Triguero et al. [2014], technological opportunities, proxied by the dummy HTech, are non-significant, although the coefficient is negative. This result is quite striking and may be due to the fact that Italian firms suffer from what Cannari et al. [2012] calls "innovative gap" with respect to other Western Countries. On one hand, high-tech firms are a little share of all firms; on the other, Italian firms are less prone to engage in $\mathrm{R} \& \mathrm{D}$, and this is true across all sectors. Additionally, high-tech firms represent less than $5 \%$ of sampled firms. For these reasons, the model might not be able to detect a significant effect for this variable.

MARKET POWER. Columns (I) include a "traditional" measure of market power: the price-cost margin (PCM). Estimated coefficients tend to be positive and would the hypothesis according to which market power disincentives innovative effort. Besides, in Section 2.3.1, we pointed out that pricecost margin is a very noisy proxy.

Hence, in columns (3), (7), we have used our implied demand elasticity measure, $-\eta$. Obtained coefficients are negative, although just slightly significant. This would support the Schumpeterian hypothesis of a positive relationship between market power and innovation, and possibly the "success-bread-success" effect.

uncertainty. The Bloom Index of Economic Policy Uncertainty [Baker et al., 2013] captures uncertainty and macroeconomic effects. ${ }^{17}$ The coefficient is significant and negative across all specifications, upholding the theory of sunk costs: since investment in R\&D incurs flow adjustment cost (while stock adjustments are possible for physical capital), uncertainty

16 Alternatively, we had used the ratio of revenues from export to total revenues, and a dummy for "big exporters" (where a big export is defined as a firm whose ratio of revenues from export to total revenues is larger that 0.27 , the $75^{\text {th }}$ percentile of the ratio distribution). Estimated coefficients are coherent with those reported.

17 All models were estimated with time-dummies as an alternative to the Bloom Index. Temporal effects' coefficients are jointly significant and negative. 
makes firms to be less reactive in their decision-making ("caution" effect), strengthening the dynamic link between current and past R\&D activity [Bloom, 2006, Geroski et al., 2007].

CONTROL VARIABLES. The literature usually finds negative and significant coefficients for firm's age and/or size, when innovation output is used as dependent variable (innovation or patent count, share of innovative sales). Such variables turn out to be non-significant in most of considered specifications, apart firms' size in models (7). Consistently with the observation of Hall [2011], we argue that larger firms can diversify their activities and are therefore more likely to persist in R\&D investment.

As in [Angelini and Generale, 2008], we also control for group membership, in order to proxy for the absence of financial constraints. Participation in an industrial group may gain the firm access to funds through the holding company. No significant effect is found for our data.

The effect of ownership as captured by the dummy Family, turns out to be not relevant, or at least negative in few specifications. Consider that, on one hand, family-owned firms should be expected to have long-term investment horizons: owners hold significant stakes and have less agency problems (as owners usually are also managers, and have strong ties with the company since property is often passed down the generations), thus they have higher incentives to ensure their firm does not under-invest in R\&D. On the other hand, family-owned firms may be more risk-adverse, as families invest a significant amount of their own wealth in the company [Munari et al., 2010]. Moreover, Hecker and Ganter [2014] suggest that family business whose management control and ownership pass down to the next generation are likely to be affected by some degree of organisational inefficiency, since the pool of potential talent of the management is reduced. Hence, data on family ownership alone may not be sufficient to shed light on this issue.

Lastly, we used dummies for geographical area (Centre, South), holding Northern Italy as reference, to proxy for institutional quality differences at the regional level. Coefficient are positive, and South's are higher and significant. As reported in Jappelli et al. [2002], judicial institutions (measured by the length of civil trial and count of pending lawsuits) are less efficient in Southern Italy, making contract enforcement uncertain and more costly for firms. Court inefficiency depresses market performance and availability of loans, which in turn reflects negatively on the propensity to engage in risky projects (like research and development). 
Table 6: Results for the Discrete-Time Models.

\begin{tabular}{|c|c|c|c|c|c|c|c|c|c|c|c|c|}
\hline & & $\begin{array}{c}\text { Cloglog } \\
\text { ailty: Norm }\end{array}$ & & & $\begin{array}{l}\text { Cloglog } \\
\text { illty: Gamn }\end{array}$ & & Frai & $\begin{array}{l}\text { Cloglog } \\
\text { ty: Mass P }\end{array}$ & ints & & $\begin{array}{c}\text { Probit }^{\dagger} \\
\text { railty: Norm }\end{array}$ & \\
\hline & (1a) & (за) & (7a) & (1b) & $(3 b)$ & $(7 \mathrm{~b})$ & (1c) & (3c) & $(7 \mathrm{c})$ & (1d) & (3d) & $(7 \mathrm{~d})$ \\
\hline \multicolumn{13}{|l|}{ Cumulativeness } \\
\hline $\ln R D_{t}$ & $\begin{array}{c}-0.124^{* * *} \\
(0.0000)\end{array}$ & $\begin{array}{c}-0.162^{* * *} \\
(0.0000)\end{array}$ & & $\begin{array}{l}-0.132^{* * *} \\
(0.0000)\end{array}$ & $\begin{array}{c}-0.172^{* * *} \\
(0.0000)\end{array}$ & & $\begin{array}{l}-0.135^{* * *} \\
(0.0000)\end{array}$ & $\begin{array}{c}-0.172^{* * *} \\
(0.0000)\end{array}$ & & $\begin{array}{l}-0.037^{* *} \\
(0.0198)\end{array}$ & $\begin{array}{c}-0.079^{* * *} \\
(0.0011)\end{array}$ & \\
\hline $\ln R D_{t-1}$ & & & $\begin{array}{c}-0.050^{* * * *} \\
(0.0011)\end{array}$ & & & $\begin{array}{c}-0.080^{* * * *} \\
(0.0001)\end{array}$ & & & $\begin{array}{c}-0.079^{* * * *} \\
(0.0000)\end{array}$ & & & $\begin{array}{c}-0.017 \\
(0.1489)\end{array}$ \\
\hline Spell Number & $\begin{array}{c}-0.001 \\
(0.9923)\end{array}$ & $\begin{array}{c}-0.015 \\
(0.8965)\end{array}$ & $\begin{array}{c}0.023 \\
(0.8135)\end{array}$ & $\begin{array}{c}0.004 \\
(0.9684)\end{array}$ & $\begin{array}{c}-0.106 \\
(0.3758)\end{array}$ & $\begin{array}{c}0.083 \\
(0.5750)\end{array}$ & $\begin{array}{c}0.012 \\
(0.9151)\end{array}$ & $\begin{array}{c}-0.106 \\
(0.3766)\end{array}$ & $\begin{array}{c}0.067 \\
(0.6391)\end{array}$ & $\begin{array}{c}-0.106 \\
(0.3580)\end{array}$ & $\begin{array}{c}-0.096 \\
(0.4450)\end{array}$ & $\begin{array}{c}-0.015 \\
(0.8483)\end{array}$ \\
\hline Time & $\begin{array}{c}-0.112^{* * * *} \\
(0.0011)\end{array}$ & $\begin{array}{c}-0.164^{* * * *} \\
(0.0000)\end{array}$ & $\begin{array}{c}-0.129^{* * *} \\
(0.0002)\end{array}$ & $\begin{array}{l}-0.0094^{*} \\
(0.0797)\end{array}$ & $\begin{array}{c}(0.3750) \\
-0.041 \\
(0.2368)\end{array}$ & $\begin{array}{c}0.578 \\
(0.3525)\end{array}$ & $\begin{array}{l}-0.083 \\
(0.2060)\end{array}$ & $\begin{array}{c}(0.37041 \\
-0.041 \\
(0.2594)\end{array}$ & $\begin{array}{c}0.046 \\
(0.3606)\end{array}$ & $\begin{array}{c}-0.050^{*} \\
(0.0977)\end{array}$ & $\begin{array}{c}(0.4450) \\
-0.079^{* * *} \\
(0.0026)\end{array}$ & $\begin{array}{c}-0.047^{* * *} \\
(0.0012)\end{array}$ \\
\hline \multicolumn{13}{|l|}{ Left Censoring } \\
\hline Left Cens & $\begin{array}{c}-0.358^{* * *} \\
(0.0004)\end{array}$ & $\begin{array}{c}-0.398^{* * *} \\
(0.0000)\end{array}$ & $\begin{array}{c}-0.487^{* * *} \\
(0.0000)\end{array}$ & $\begin{array}{c}-0.387^{* * *} \\
(0.0017)\end{array}$ & $\begin{array}{c}-0.765^{* * *} \\
(0.000)\end{array}$ & $\begin{array}{c}-0.711^{* * *} \\
(0.0001)\end{array}$ & $\begin{array}{c}-0.394^{* * *} \\
(0.0049)\end{array}$ & $\begin{array}{c}-0.766^{* * *} \\
(0.0000)\end{array}$ & $\begin{array}{c}-0.717^{* * *} \\
(0.0001)\end{array}$ & $\begin{array}{c}-0.267^{* * *} \\
(0.0001)\end{array}$ & $\begin{array}{c}-0.294^{* * *} \\
(0.0001)\end{array}$ & $\begin{array}{c}-0.319^{* * * *} \\
(0.0001)\end{array}$ \\
\hline \multicolumn{13}{|l|}{ Investment } \\
\hline IM & $\begin{array}{c}0.089 \\
(0.8500)\end{array}$ & $\begin{array}{c}1.096 \\
(0.3099)\end{array}$ & & $\begin{array}{c}0.125 \\
(0.7391)\end{array}$ & $\begin{array}{c}1.407 \\
(0.2177)\end{array}$ & & $\begin{array}{c}0.137 \\
(0.7111)\end{array}$ & $\begin{array}{c}1.411 \\
(0.2170)\end{array}$ & & $\begin{array}{c}0.225 \\
(0.5353)\end{array}$ & $\begin{array}{c}0.346 \\
(0.6961)\end{array}$ & \\
\hline$\Delta \mathrm{IM}$ & & & $\begin{array}{c}0.303 \\
(0.8238)\end{array}$ & & & $\begin{array}{c}0.618 \\
(0.7080)\end{array}$ & & & $\begin{array}{c}0.735 \\
(0.6440)\end{array}$ & & & $\begin{array}{c}0.091 \\
(0.8803)\end{array}$ \\
\hline IS & $\begin{array}{c}-25.656^{* *} \\
(0.0117)\end{array}$ & $\begin{array}{l}-23.304^{*} \\
(0.0662)\end{array}$ & & $\begin{array}{c}-31.461^{* *} \\
(0.0332)\end{array}$ & $\begin{array}{c}-37.888^{* *} \\
(0.0442)\end{array}$ & & $\begin{array}{c}-33.147^{* *} \\
(0.0309)\end{array}$ & $\begin{array}{c}-38.422^{* *} \\
(0.0427)\end{array}$ & & $\begin{array}{c}-16.407^{* *} \\
(0.0363)\end{array}$ & $\begin{array}{c}-8.892 \\
(0.2883)\end{array}$ & \\
\hline$\Delta \mathrm{IS}$ & & & $\begin{array}{c}-7.993 \\
(0.3806)\end{array}$ & & & $\begin{array}{c}-0.546 \\
(0.9545)\end{array}$ & & & $\begin{array}{c}-0.801 \\
(0.9318)\end{array}$ & & & $\begin{array}{c}-13.590^{* *} \\
(0.0337)\end{array}$ \\
\hline \multicolumn{13}{|l|}{ Finances } \\
\hline $\mathrm{CF}_{\mathrm{t}}$ & $\begin{array}{c}-0.809 \\
(0.2524)\end{array}$ & $\begin{array}{l}-0.900^{*} \\
(0.0756)\end{array}$ & & $\begin{array}{c}-2.155^{* * *} \\
(0.0056)\end{array}$ & $\begin{array}{c}-1.083 \\
(0.1043)\end{array}$ & & $\begin{array}{c}-2.193^{* * *} \\
(0.0057)\end{array}$ & $\begin{array}{l}-1.084 \\
(0.1043)\end{array}$ & & $\begin{array}{l}-0.202 \\
(0.7222)\end{array}$ & $\begin{array}{c}-0.592^{*} \\
(0.0851)\end{array}$ & \\
\hline $\mathrm{CF}_{\mathrm{t}-1}$ & & & $\begin{array}{c}-0.439 \\
(0.4950)\end{array}$ & & & $\begin{array}{l}-1.671^{*} \\
(0.0621)\end{array}$ & & & $\begin{array}{l}-1.670^{*} \\
(0.0528)\end{array}$ & & & $\begin{array}{c}-0.278 \\
(0.6219)\end{array}$ \\
\hline$D_{t}$ & $\begin{array}{c}0.158 \\
(0.2608)\end{array}$ & $\begin{array}{c}0.146 \\
(0.3149)\end{array}$ & & $\begin{array}{c}0.132 \\
(0.4766)\end{array}$ & $\begin{array}{c}0.268 \\
(0.2837)\end{array}$ & & $\begin{array}{c}0.137 \\
(0.4673)\end{array}$ & $\begin{array}{c}0.268 \\
(0.2835)\end{array}$ & & $\begin{array}{c}-0.280 \\
(0.1284)\end{array}$ & $\begin{array}{c}-0.163 \\
(0.4340)\end{array}$ & \\
\hline$D_{t-1}$ & & & $\begin{array}{c}0.304 \\
(0.1969)\end{array}$ & & & $\begin{array}{c}0.533^{*} \\
(0.0959)\end{array}$ & & & $\begin{array}{l}0.527^{*} \\
(0.0891)\end{array}$ & & & $\begin{array}{c}0.134 \\
(0.5567)\end{array}$ \\
\hline \multicolumn{13}{|c|}{ International Competition } \\
\hline Exp & $\begin{array}{c}0.032 \\
(0.6952)\end{array}$ & $\begin{array}{l}-0.178^{* *} \\
(0.0116)\end{array}$ & $\begin{array}{c}-0.240^{* * * *} \\
(0.0085)\end{array}$ & $\begin{array}{c}-0.069 \\
(0.4663)\end{array}$ & $\begin{array}{c}-0.137 \\
(0.2477)\end{array}$ & $\begin{array}{c}-0.119 \\
(0.4375)\end{array}$ & $\begin{array}{c}-0.072 \\
(0.4545)\end{array}$ & $\begin{array}{c}-0.137 \\
(0.2486)\end{array}$ & $\begin{array}{c}-0.109 \\
(0.4717)\end{array}$ & $\begin{array}{c}0.027 \\
(0.5887)\end{array}$ & $\begin{array}{l}-0.114^{* *} \\
(0.0306)\end{array}$ & $\begin{array}{l}-0.147^{* *} \\
(0.0186)\end{array}$ \\
\hline
\end{tabular}




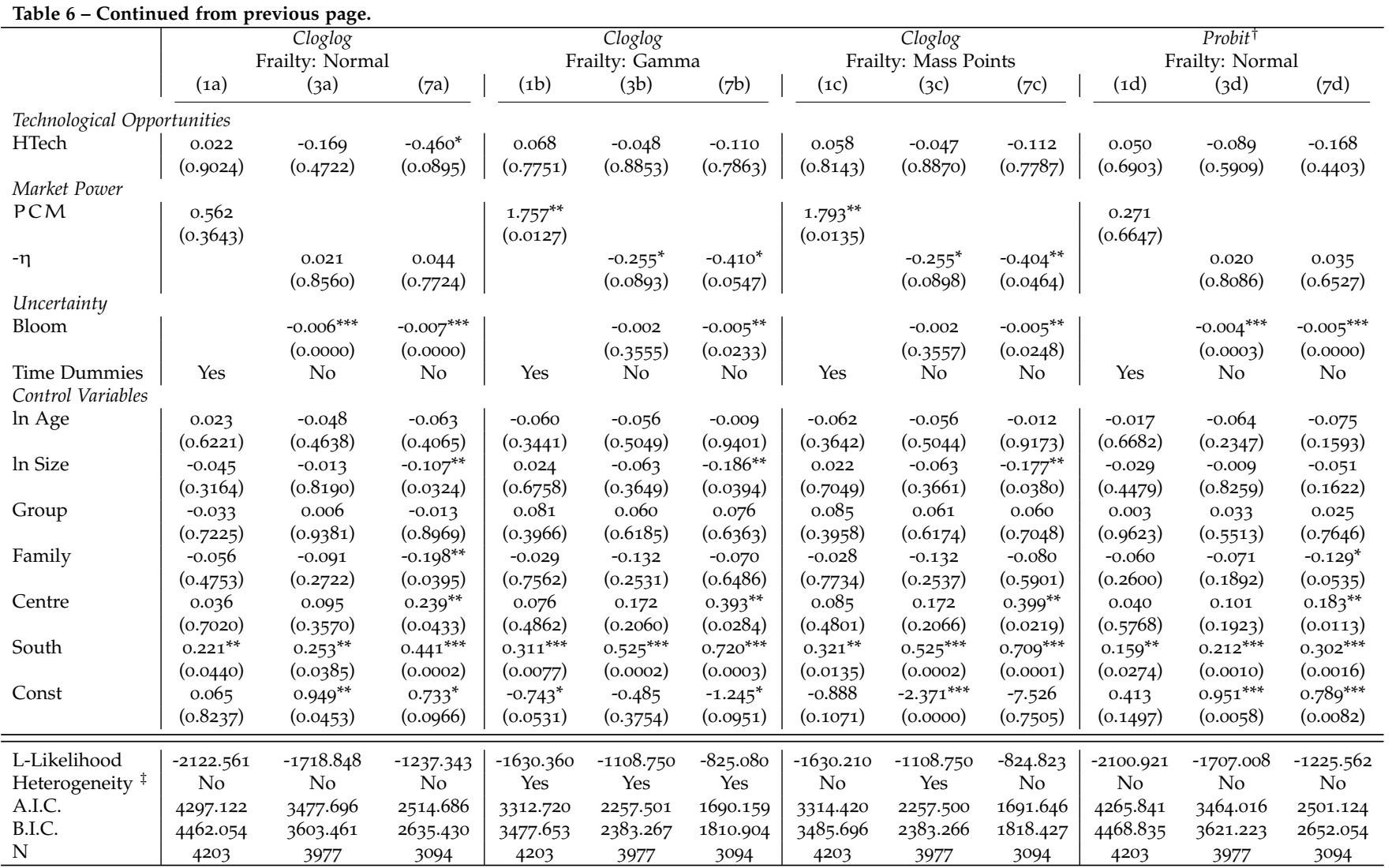

(†) The Probit model includes the mean values of all continuous variables. Coefficient are reported in Table 12. ( $\ddagger)$ The presence of heterogeneity is tested for in Tables 9 , 10, $11,12$. 


\section{CONCLUSIONS}

This study examines the matter of innovation persistence, represented by the length of the innovative spells firms experience, exploiting a duration analysis framework. Our sample consists of R\&D engaged Italian firms drawn from the survey data set by the Bank of Italy within the period 20032012. The availability of firm-level panel data allows for the distinction between spurious persistence (innovation is caused by time-invariant unobserved firm characteristics that are exogenous to the sequence of innovative events, but determine its initial conditions) and true persistence (intertemporal spill overs between subsequent innovation activities).

We primarily followed the approach presented by Máñez et al. [2014], adding some important contributions of our own by expanding the set of variables that test for true persistence ("sunk-cost" and "success-breadssuccess" effects), and testing the Proportional Hazard assumption to hold in the Cox and Cloglog models, which allowed us to reject the Cox model as biased. Within a discrete time framework, we estimated a Cloglog model, for which the assumption of $\mathrm{PH}$ holds, once unobserved heterogeneity is controlled for, and a random effect Probit model, that does not assume Proportional Hazards.

We find that innovative behaviour is persistent: past experience is an incentive to remain an $R \& D$ performer. This signals the presence of important temporal spill overs that reflect the cumulability of knowledge ("learningby-doing" effect). The "success-bread-success" effect is also verified, since the negative coefficients of the variables $C F$ and $-\eta$ signal that firms that have internal funds available and enjoy some degree of market power are better able to sustain the expenses connected with research and development activities. Furthermore, the presence of important sunk costs is supported by the negative and significant estimated coefficients of the Bloom Index, a rise in which causes firms be less reactive in their decisions about investments ("caution" effect). Also, the non-significant coefficients for $\triangle I M$ and $\Delta \mathrm{IS}$ reveal that the continuity of R\&D activity is not related to unexpected variations in physical and software investment, consistently with the fact that, while such expenses incur stock adjustment costs, expenditures connected with innovation tend to be more persistent. This evidence would suggest that R\&D spending is a path-dependent process, as confirmed by the fact that relatively time-invariant firm characteristics are often non significant and unobserved heterogeneity seems to play little role.

As for market power, different measures lead to different results. While PCM's coefficients are positive (i.e. the higher the PCM, the higher is the probability that an innovation-engaged firm will discontinue investment); elasticity's coefficients are negative. We would argue that these results, which are not conclusive, underline the importance of finding better proxies for the measurement of market power. As pointed out by Boone [2000, 2001, 2008], Coscollá-Girona et al. [2011], one should take into account the fact that different efficiency level imply different responses to increases in competitive pressure. Even though the data did not allow us to account for firm efficiency, we would argue that our measure of implied elasticity is better suited to capture market power than PCM. 
Some questions are open to further research: first of all, more attention should be directed to the construction of valid measures for market power, since traditional ones (like PCM) are likely to be insufficient for describing competitive pressure. We would argue that our measure, that accounts for a microeconomics concept such as firm demand elasticity, may be an appropriate one, provided that data about it were collected yearly, in order to capture long-run dynamics.

Secondly, within this framework we were not able to distinguish the general event "interruption of R\&D investment" from other events, e.g. exit from the market, or acquisition. We are stating the obvious when we argue that exit from the innovative state and exit from the market are events driven by different underlying processes. Furthermore, it would be interesting to develop such an approach as in [Balcaen et al., 2012], where different types of exit from the market are considered, in a competing-risk model approach. It seems reasonable to think that, for instance, a firm that successfully innovates but is not able to fully appropriate the returns of its effort (e.g. because it does not have the resource to properly advertise and distribute its products) may be acquired by a bigger firm. In this case we would observe an interruption in R\&D investment on behalf of the acquired firm. In order to establish the continuity of innovative effort, though, it might be desirable to take into account that R\&D activity was not discontinued, just transferred to another firm. Such a study would make our comprehension about innovation dynamics more precise, allowing to properly assess the effect of each variable on different events.

\section{REFERENCES}

Acs, Z. J. and Audretsch, D. B. (1988). Innovation in Large and Small Firms: an Empirical Analysis. The American Economic Review, 78(4):678-69o.

Acs, Z. J., Braunerhjelm, P., Audretsch, D. B., and Carlsson, B. (2008). The Knowledge Spillover Theory of Entrepreneurship. Small Business Economics, 32:15-30.

Aghion, P., Bloom, N., Blundell, R., Griffith, R., and Howitt, P. (2002). Competition and Innovation: an Inverted U Relationship. National Bureau of Economical Research, NBER Working Paper(9269).

Angelini, P. and Generale, A. (2008). On the Evolution of Firm Size Distributions. The American Economic Review, 98(1):426-438.

Antonelli, C., Crespi, F., and Scellato, G. (2012a). Internal and External Factors in Innovation Persistence. University of Torino, Working Paper(11).

Antonelli, C., Crespi, F., Scellato, G., and Cognetti (2012b). Inside Innovation Persistence: New Evidence from Italian Micro-data. University of Torino, Working Paper(13).

Arrow, K. J. (1962). Economic Welfare and the Allocation of Resources for Invention. In Nelson, R. R., editor, The Rate and Direction of Inventive Activity Economic and Social Factors, pages 609-626. Princeton University Press. 
Audretsch, D. B. (1991). New-Firm Survival and the Technological Regime. The Review of Economics and Statistics, 73(3):441-450.

Audretsch, D. B. (1995). Innovation, Growth and Survival. International Journal of Industrial Organization, 13:441-457.

Baker, S. R., Bloom, N., and Davis, S. J. (2013). Measuring economic policy uncertainty. Chicago Booth Research, Chicago Booth Research Paper(1302).

Balcaen, S., Manigart, S., Buyze, J., and Ooghe, H. (2012). Firm Exit after Distress: Differentiating between Bankruptcy, Voluntary Liquidation and M\&A. Small Business Economics, 39:949-975.

Banbury, C. M. and Mitchell, W. (1995). The Effect of Introducing Important Incremental Innovations on Market Share and Business Survival. Strategic Management Journal, 16:161-182.

Banca d'Italia (2008). Survey of Industrial and Service Firms, Year 2007. New Series, XVIII(42).

Banca d'Italia (2013). Survey of Industrial and Service Firms, Year 2012. New Series, XXIII(38).

Bartoloni, E. and Baussola, M. (2009). The Persistence of Profits, Sectoral Heterogeneity and Firms' Characteristics. International Journal of the Economics of Business, 16(1):87-111.

Bhattacharjee, A., Higson, C., Holly, S., and Kattuman, P. (2002). Marco Economic Instability and Business Exit: Determinants of Failures and Acquisitions of Large UK Firms. University of Cambridge, (0206).

Bloom, N. (2006). Uncertainty and the Dynamics of R\&D. American Economic Review, 97(2):250-255.

Blundell, R., Griffith, R., and Reenen, J. V. (1999). Market Share, Market Value and Innovation in a Panel of British Manufacturing Firms. The Review of Economic Studies, 66(3):529-554.

Bontempi, M. E. (2003). The Dynamic Specification of the Modified Pecking Order Theory its Relevance to Italy. Empirical Economics, 27(1):1-22.

Bontempi, M. E. (2016). Investment-Uncertainty Relationship Difference between Intangible and Physical Capital. Economics of Innovation and New Technology, (forthcoming).

Bontempi, M. E., Golinelli, R., and Parigi, G. (2010). Why Demand Uncertainty Curbs Investment: Evidence from a Panel of Italian Manufacturing Firms. Journal of Macroeconomics, 32(32):218-238.

Bontempi, M. E. and Mairesse, J. (2015). Intangible Capital and Productivity at the Firm Level: a Panel Data Assessment. Economics of Innovation and New Technology, 24(1-2):22-51.

Boone, J. (2000). Competitive Pressure: the Effects on Investments in Product and Process innovation. The RAND Journal of Economics, 31(3):549-569.

Boone, J. (2001). Intensity of Competition and the Incentive to Innovate. International Journal of Industrial Organization, 19(5):705-726. 
Boone, J. (2008). Competition: Theoretical Parameterizations and Empirical Measures. Journal of Institutional and Theoretical Economics, 164:587-611.

Brenton, P., Saborowski, C., and Von Uexkull, E. (2009). What Explains the Low Survival Rate of Developing Country Export Flows? The World Bank, International Trade Department, Policy Research Working Pa$\operatorname{per}(4951)$.

Bronzini, R. and Piselli, P. (2006). Determinants of Long-run Regional Productivity: the Role of R\&D, Human Capital and Public Infrastructure. Banca d'Italia, Temi di Discussione del Servizio Studi(597).

Bublitz, B. and Ettredge, M. (1989). The Information in Discretionary Outlays: Advertising, Research and Development. The Accounting Review, 64(1):108-124.

Cannari, L., Bugamelli, M., Lotti, F., and Magri, S. (2012). Il Gap Innovativo del Sistema Produttivo Italiano: Radici e Possibili Rimedi. Banca d'Italia, Questioni di Economia e Finanza (Occasional Papers)(121).

Carter, D. B. and Signorino, C. S. (2013). Good Times, Bad Times: Left Censoring in Grouped Binary Duration Data.

Cefis, E. and Ciccarelli, M. (2005). Profit Differentials and Innovation. Economics of Innovation and New Technology, 14(1-2):43-61.

Cefis, E. and Marsili, O. (2004). A Matter of Life and Death: Innovation and Firm Survival. Industrial and Corporate Change, 14(6).

Coscollá-Girona, P., López, P. B., Llopis, A. S., and Barrachina, M. E. R. (2011). Competitive Pressure Determinants and Innovation at the Firm Level. Working Papers. Serie EC 2011-02, Instituto Valenciano de Investigaciones Económicas, S.A. (Ivie).

Crépon, B., Duguet, E., and Mairesse, J. (1998). Research, Innovation and Productivity: an Econometric Analysis at the Firm Level. National Bureau of Economic Research, NBER Working Paper Series(6696).

Domowitz, I., Hubbard, R. H., and Petersen, B. C. (1986). Business Cycles and the Relationship between Concentration and Price-Cost Margins. The RAND Journal of Economics, 17(1):1-17.

Doms, M., Dunne, T., and Roberts, M. J. (1995). The Role of Technology Use in the Survival and Growth of Manifacturing Plants. International Journal of Industrial Organization, 13:523-542.

Duguet, E. and Monjon, S. (2004). Is innovation Persistent at the Firm Level: an Econometric Examination comparing the Propensity Score and Regression Methods. Université Panthéon-Sorbonne (Paris 1), Cahiers de la Maison des Sciences Economiques(v04075).

Geroski, P. A. (1989). Entry, Innovation and Productivity Growth. The Review of Economics and Statistics, 71(4):572-578.

Geroski, P. A., Mata, J., and Portugal, P. (2007). Founding Conditions and the Survival of New Firms. Danish Research Unit for Industrial Dynamics, DRUID Working Paper(07-11).

Gort, M. and Klepper, S. (1982). Time Paths in The Diffusion of Product Innovations. The Economic Journal, 92(367):630-653. 
Greene, W. H. (2005). Censored Data and Truncated Distributions. In Greene, W. H., editor, Econometric Analysis, pages 695-734. Prentice Hall.

Greenhalgh, C. and Rogers, M. (2006). The Value of Innovation: the Interaction of Competition, R\&D and IP. Research Policy, 35(4):562-580.

Griliches, Z. (1998). Issues in Assessing the Contribution of Research and Development to Productivity Growth. In Griliches, Z., editor, RED and Productivity: The Economic Evidence, chapter 2, pages 17-45. University of Chicago Press.

Guiso, L., Pistaferri, L., and Raghu, S. (2006). Investment plans. Working Paper.

Hall, B. H. (2011). Innovation and Productivity. National Bureau of Economic Research, NBER Working Paper Series(17178).

Hecker, A. and Ganter, A. (2014). Path and Past Dependence of Firm Innovation. Economics of Innovation and New Technology, 23(5-6):563-583.

Hess, W. and Persson, M. (2010). The Duration of Trade Revisited: Continuous-Time vs. Discrete-Time Hazards. Research Institute of Industrial Economics, Working Paper(829).

Hirschey, M. (1982). Intangible Capital Aspects of Advertising and R\&D Expenditures. The Journal of Industrial Economics, 30(4):375-39o.

Huang, C.-H. (2008). A Note on the Persistence of Firms' Innovation Behavior: a Dynamic Random Effect Probit Model Approach. Economics Bulletin, 15(5):1-9.

Iceland, J. (1997). The Dynamics of Poverty Spells and Issues of LeftCensoring. PSC Research Report Series, (378).

Jappelli, T., Pagano, M., and Bianco, M. (2002). Courts and Banks : Effects of Judicial Enforcement on Credit Markets. Centre for Studies in Economics and Finance, CSEF, Working Paper(58).

Jenkins, S. (2005). Survival Analysis. Unpublished.

Kiefer, N. M. (1988). Economic Duration Data and Hazard Functions. Journal of Economic Literature, 26(2):646-679.

Lancaster, T. (1979). Econometric Methods for the Duration of Unemployment. Econometrica, 47(4):939-956.

Le Bas, C. and Scellato, G. (2014). Firm Innovation Persistence: a Fresh Look at the Frameworks of Analysis. Economics of Innovation and New Technology, 23(5-6):423-446.

Lhuillery, S. (2014). Marketing and Persistent Innovation Success. Economics of Innovation and New Technology, 23(5-6):517-543.

Lööf, H., Nabavi Larjiani, P., Cook, G., and Johansson, B. (2015). Learningby-Exporting and Innovation Strategies. Economics of Innovation and New Technology, 24(1-2):52-64.

López-García, P. and Puente, S. (2006). Business Demography in Spain: Determinants of Firm Survival. Documentos de Trabajo, Banco de España, (0608). 
Máñez, J. A., Rochina-Barrachina, M. E., Sanchis-Llopis, A., and SanchisLlopis, J. A. (2014). The determinants of R\&D persistence in SMEs. Small Business Economics.

Mairesse, J. and Robin, S. (2009). Innovation and productivity: a firm-level analysis for French Manufacturing and Services using $\mathrm{CIS}_{3}$ and $\mathrm{CIS}_{4}$ data (1998-2000 and 2002-2004). Paris, France: CREST-ENSAE.

Masso, J. and Vahter, P. (2008). Technological Innovation and Productivity in Late-Transition Estonia: Econometric Evidence from Innovation Surveys. The European Journal of Development Research, 20(2):240-261.

Munari, F., Oriani, R., and Sobrero, M. (2010). The Effects of Owner Identity and External Governance Systems on R\&D Investments: A Study of Western European Firms. Research Policy, 39(8):1093-1104.

Parisi, M. L., Schiantarelli, F., and Sembenelli, A. (2006). Productivity, Innovation and R\&D: Micro Evidence for Italy. European Economic Review, 50:2037-2061.

Peters, B. (2006). Persistence of Innovation: Stylised Facts and Panel Data Evidence. Danish Research Unit for Industrial Dynamics, DRUID Working Paper(06-30).

Polder, M., Van Leeuwen, G., Mohnen, P., and Raymond, W. (2009). Productivity Effects of Innovation Modes. The Hague, NE: Statistics Netherlands, (18893).

Schumpeter, J. A. (1943). Capitalism, Socialism and Democracy. G. Allen \& Unwin Ltd., London.

StataCorp. (2013). Stata 13 base reference manual. Technical report, College Station, TX.

Stevens, A. H. (1995). Climbing out of Poverty, Falling back in: Measuring the Persistence of Poverty over Multiple Spells. National Bureau of Economical Research, NBER Working Paper Series(5390).

Tirole, J. (1988). The Theory of Industrial Organization. The MIT Press, Cambridge, MA.

Triguero, A. and Córcoles, D. (2013). Understanding Innovation: an Analysis of Persistence for Spanish Manufacturing Firms. Research Policy, $42(2): 340-352$.

Triguero, A., Córcoles, D., and Cuerva, M. C. (2014). Measuring the Persistence in Innovation in Spanish Manufacturing Firms: Empirical Evidence Using Discrete-Time Duration Models. Economics of Innovation and New Technology, 23(5-6):447-468.

Van Leeuwen, G. and Klomp, L. (2006). On the contribution of innovation to multi-factor productivity growth. Economics of Innovation and New Technology, 15(4/5):367-390.

Verbeek, M. (2004). A Guide to Modern Econometrics. John Wiley $\backslash \&$ Sons, Ltd., 2nd edition.

Woerter, M. (2014). Competition and Persistence of R\&D. Economics of Innovation and New Technology, 23(5-6):469-489. 
Wooldridge, J. M. (2002). Econometric Analysis of Cross Section and Panel Data. The MIT Press, Cambridge, MA. 


\section{A APPENDIX}

Table 7: Sample vs. Working Sample: Time-Invariant Variables.

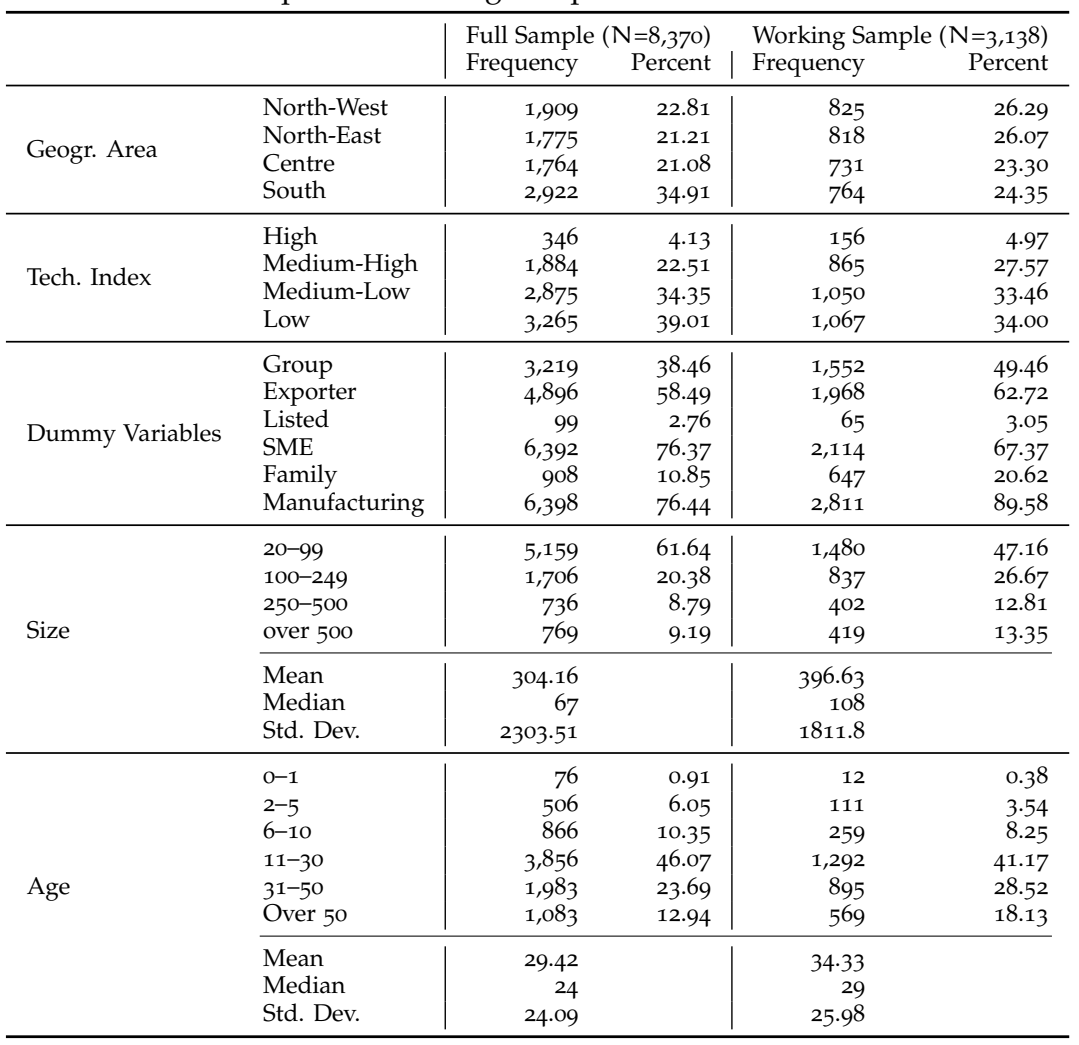

In order to obtain descriptive statistics which are not influenced by the different number of observations per firm, we have used the first available observation for each firm from 2003 onwards. This description is representative of the sample due to the relatively time-invariant nature of the reported variables. 
Table 8: Robustness Checks for the Cox Model with no Frailty.

\begin{tabular}{|c|c|c|c|c|c|c|c|}
\hline & (1) & (2) & (3) & (4) & (5) & (6) & (7) \\
\hline \multicolumn{8}{|l|}{ Cumulativeness } \\
\hline $\ln R D_{t}$ & $\begin{array}{l}-0.050^{* *} \\
(0.0011)\end{array}$ & $\begin{array}{l}-0.111^{* * *} \\
(0.0000)\end{array}$ & $\begin{array}{c}-0.109^{* * *} \\
(0.0000)\end{array}$ & $\begin{array}{c}-0.118^{* * *} \\
(0.0000)\end{array}$ & $\begin{array}{c}-0.109^{* * *} \\
(0.0000)\end{array}$ & & \\
\hline $\ln R D_{t-1}$ & & & & & & $\begin{array}{c}-0.087^{* * *} \\
(0.0000)\end{array}$ & $\begin{array}{c}-0.097^{* * *} \\
(0.0000)\end{array}$ \\
\hline Spell Number & $\begin{array}{l}-4.135^{* * *} \\
\text { (o.0000) }\end{array}$ & $\begin{array}{c}-3.220^{* * *} \\
(0.0000)\end{array}$ & $\begin{array}{c}-3.152^{* * *} \\
(0.0000)\end{array}$ & $\begin{array}{c}-3.140^{* * *} \\
(0.0000)\end{array}$ & $\begin{array}{c}-3.055^{* * *} \\
(0.0000)\end{array}$ & $\begin{array}{c}-2.68 \mathrm{O}^{* * *} \\
(0.0000)\end{array}$ & $\begin{array}{c}-2.500^{* * *} \\
(0.0000)\end{array}$ \\
\hline Time & $\begin{array}{c}-1.345^{* * *} \\
(0.0000)\end{array}$ & $\begin{array}{c}-1.109^{* * *} \\
(0.0000)\end{array}$ & $\begin{array}{c}-1.084^{* * *} \\
(0.0000)\end{array}$ & $\begin{array}{c}-1.103^{* * *} \\
(0.0000)\end{array}$ & $\begin{array}{c}-1.086^{* * *} \\
(0.0000)\end{array}$ & $\begin{array}{c}-0.974^{* * *} \\
(0.0000)\end{array}$ & $\begin{array}{c}-0.907^{* * *} \\
\text { (o.0000) }\end{array}$ \\
\hline \multicolumn{8}{|l|}{ Left Censoring } \\
\hline Left Cens. & $\begin{array}{c}-0.003 \\
(0.9687)\end{array}$ & $\begin{array}{l}0.257^{* * *} \\
(0.0005)\end{array}$ & $\begin{array}{c}0.121 \\
(0.0803)\end{array}$ & $\begin{array}{l}0.252^{* * *} \\
(0.0010)\end{array}$ & $\begin{array}{c}0.138 \\
(0.0912)\end{array}$ & $\begin{array}{l}0.358^{* * *} \\
\text { (o.0009) }\end{array}$ & $\begin{array}{c}0.146 \\
(0.2173)\end{array}$ \\
\hline \multicolumn{8}{|l|}{ Investments } \\
\hline IM & $\begin{array}{c}0.334 \\
(0.4453)\end{array}$ & $\begin{array}{l}1.157^{* *} \\
(0.0042)\end{array}$ & $\begin{array}{l}1.252^{* *} \\
(0.0021)\end{array}$ & & & $\begin{array}{c}1.388^{*} \\
(0.0153)\end{array}$ & \\
\hline$\Delta \mathrm{IM}$ & & & & $\begin{array}{c}1.009 \\
(0.2475)\end{array}$ & $\begin{array}{c}0.313 \\
(0.6951)\end{array}$ & & $\begin{array}{c}0.702 \\
(0.4352)\end{array}$ \\
\hline IS & $\begin{array}{l}-15.842^{*} \\
(0.0464)\end{array}$ & $\begin{array}{l}-19.979 \\
(0.0870)\end{array}$ & $\begin{array}{c}-25.28 \mathrm{o}^{* *} \\
(0.0032)\end{array}$ & & & $\begin{array}{l}-28.969^{*} \\
(0.0455)\end{array}$ & \\
\hline$\Delta \mathrm{IS}$ & & & & $\begin{array}{c}-4.917 \\
(0.3913)\end{array}$ & $\begin{array}{c}-7.261 \\
(0.2977)\end{array}$ & & $\begin{array}{l}-12.404 \\
(0.1247)\end{array}$ \\
\hline \multicolumn{8}{|l|}{ Finances } \\
\hline$C F_{t}$ & $\begin{array}{c}0.361 \\
(0.5507)\end{array}$ & $\begin{array}{c}0.286 \\
(0.4145)\end{array}$ & $\begin{array}{c}0.670 \\
(0.2112)\end{array}$ & $\begin{array}{c}0.588 \\
(0.2125)\end{array}$ & $\begin{array}{c}0.953 \\
(0.0790)\end{array}$ & & \\
\hline$C F_{t-1}$ & & & & & & $\begin{array}{c}0.507 \\
(0.4284)\end{array}$ & $\begin{array}{c}0.834 \\
(0.2469)\end{array}$ \\
\hline $\mathrm{D}_{\mathrm{t}}$ & $\begin{array}{c}-0.281 \\
(0.0531)\end{array}$ & $\begin{array}{l}-0.540^{* *} \\
(0.0021)\end{array}$ & $\begin{array}{l}-0.407^{*} \\
(0.0315)\end{array}$ & $\begin{array}{l}-0.473^{* *} \\
(0.0021)\end{array}$ & $\begin{array}{c}-0.333 \\
(0.0802)\end{array}$ & & \\
\hline $\mathrm{D}_{\mathrm{t}-1}$ & & & & & & $\begin{array}{c}-0.087^{* * *} \\
(0.0000)\end{array}$ & $\begin{array}{c}-0.097^{* * *} \\
(0.0000)\end{array}$ \\
\hline \multicolumn{8}{|c|}{ International Competition } \\
\hline Exp & $\begin{array}{c}0.068 \\
(0.3615)\end{array}$ & $\begin{array}{c}-0.382^{* * *} \\
(0.0000)\end{array}$ & $\begin{array}{l}-0.175^{*} \\
(0.0216)\end{array}$ & $\begin{array}{c}-0.402^{* * *} \\
(0.0000)\end{array}$ & $\begin{array}{l}-0.179^{*} \\
\text { (o.0190) }\end{array}$ & $\begin{array}{c}-0.491^{* * *} \\
(0.0000)\end{array}$ & $\begin{array}{c}-0.178 \\
(0.0887)\end{array}$ \\
\hline \multicolumn{8}{|c|}{ Technological Opportunities } \\
\hline HTech & $\begin{array}{c}0.124 \\
(0.5038)\end{array}$ & $\begin{array}{l}-0.323^{*} \\
(0.0424)\end{array}$ & $\begin{array}{c}-0.200 \\
(0.3723)\end{array}$ & $\begin{array}{c}-0.449 \\
(0.0748)\end{array}$ & $\begin{array}{c}-0.314 \\
(0.1274)\end{array}$ & $\begin{array}{c}-0.364 \\
(0.1960)\end{array}$ & $\begin{array}{c}-0.357 \\
(0.1798)\end{array}$ \\
\hline \multicolumn{8}{|l|}{ Market Power } \\
\hline $\mathrm{PCM}$ & $\begin{array}{c}0.712 \\
(0.1288)\end{array}$ & & & & & & \\
\hline$-\eta$ & & $\begin{array}{c}-0.070 \\
(0.4581)\end{array}$ & $\begin{array}{c}-0.058 \\
(0.3873)\end{array}$ & $\begin{array}{c}-0.019 \\
(0.8640)\end{array}$ & $\begin{array}{c}-0.013 \\
(0.8922)\end{array}$ & $\begin{array}{c}-0.025 \\
(0.8378)\end{array}$ & $\begin{array}{c}-0.018 \\
(0.8819)\end{array}$ \\
\hline \multicolumn{8}{|l|}{ Uncertainty } \\
\hline Bloom & & & $\begin{array}{c}-0.016^{* * *} \\
(0.0000)\end{array}$ & & $\begin{array}{l}-0.017^{* * *} \\
(0.0000)\end{array}$ & & $\begin{array}{c}-0.020^{* * *} \\
(0.0000)\end{array}$ \\
\hline $\begin{array}{l}\text { Time dummies } \\
\text { Control Variables }\end{array}$ & Yes & Yes & No & Yes & No & Yes & No \\
\hline ln Age & $\begin{array}{c}0.028 \\
(0.4972)\end{array}$ & $\begin{array}{c}-0.003 \\
(0.9628)\end{array}$ & $\begin{array}{c}0.052 \\
(0.3678)\end{array}$ & $\begin{array}{c}0.006 \\
(0.9182)\end{array}$ & $\begin{array}{c}0.064 \\
(0.2816)\end{array}$ & $\begin{array}{c}-0.003 \\
(0.9626)\end{array}$ & $\begin{array}{c}0.045 \\
(0.5604)\end{array}$ \\
\hline $\ln$ Size & $\begin{array}{c}0.028 \\
(0.3263)\end{array}$ & $\begin{array}{c}-0.022 \\
(0.5800)\end{array}$ & $\begin{array}{l}-0.022 \\
(0.5894)\end{array}$ & $\begin{array}{c}0.003 \\
(0.9425)\end{array}$ & $\begin{array}{c}-0.004 \\
(0.9264)\end{array}$ & $\begin{array}{l}-0.000 \\
(0.9932)\end{array}$ & $\begin{array}{c}-0.001 \\
(0.9858)\end{array}$ \\
\hline Group & $\begin{array}{c}0.029 \\
(0.6006)\end{array}$ & $\begin{array}{c}0.136^{*} \\
(0.0396)\end{array}$ & $\begin{array}{l}0.158^{*} \\
(0.0157)\end{array}$ & $\begin{array}{c}0.142 \\
(0.0680)\end{array}$ & $\begin{array}{c}0.168^{*} \\
(0.0172)\end{array}$ & $\begin{array}{c}0.131 \\
(0.1034)\end{array}$ & $\begin{array}{c}0.152 \\
(0.1008)\end{array}$ \\
\hline Family & $\begin{array}{l}0.321^{* * *} \\
(0.0000)\end{array}$ & $\begin{array}{l}0.212^{* *} \\
(0.0028)\end{array}$ & $\begin{array}{c}0.105 \\
(0.1123)\end{array}$ & $\begin{array}{l}0.186^{* *} \\
(0.0068)\end{array}$ & $\begin{array}{c}0.076 \\
(0.3532)\end{array}$ & $\begin{array}{c}0.138 \\
(0.1385)\end{array}$ & $\begin{array}{c}-0.006 \\
(0.9563)\end{array}$ \\
\hline Centre & $\begin{array}{c}0.059 \\
(0.4995)\end{array}$ & $\begin{array}{c}0.137 \\
(0.1276)\end{array}$ & $\begin{array}{c}0.163 \\
(0.0755)\end{array}$ & $\begin{array}{c}0.150 \\
(0.0896)\end{array}$ & $\begin{array}{c}0.169 \\
(0.1185)\end{array}$ & $\begin{array}{c}0.221^{*} \\
(0.0467)\end{array}$ & $\begin{array}{c}0.238^{*} \\
(0.0407)\end{array}$ \\
\hline South & $\begin{array}{l}0.280^{* *} \\
(0.0020)\end{array}$ & $\begin{array}{c}0.203^{*} \\
(0.0187)\end{array}$ & $\begin{array}{l}0.335^{* * *} \\
(0.0002)\end{array}$ & $\begin{array}{c}0.188 \\
(0.0517)\end{array}$ & $\begin{array}{l}0.340^{* * *} \\
(0.0001)\end{array}$ & $\begin{array}{l}0.315^{* *} \\
(0.0031)\end{array}$ & $\begin{array}{l}0.478^{* * * *} \\
\text { (o.00oo) }\end{array}$ \\
\hline L-Likelihood & -5435.104 & -4072.731 & -3998.766 & -3528.991 & -3458.539 & -2567.472 & -2498.926 \\
\hline A.I.C. & 10904.208 & 8179.462 & 8033.532 & 7091.981 & 6953.078 & 5168.943 & 5033.852 \\
\hline B.I.C. & 10993.827 & 8268.626 & 8127.941 & 7179.193 & $7045 \cdot 420$ & 5253.269 & 5123.053 \\
\hline $\mathrm{N}$ & 1439 & 1401 & 1401 & 1249 & 1249 & 1054 & 1049 \\
\hline
\end{tabular}

P-values are reported in parenthesis. All estimation were run with the Stata command stcox and bootstrapped errors. This model does not control for unobserved heterogeneity. 
Table 9: Robustness Check for the Complementary Log-Logistic Model with Normally-Distributed Frailty.

\begin{tabular}{|c|c|c|c|c|c|c|c|}
\hline & (1) & (2) & (3) & （4） & （5） & (6) & (7) \\
\hline \multicolumn{8}{|l|}{ Cumulativeness } \\
\hline $\ln \mathrm{RD}_{\mathrm{t}}$ & $\begin{array}{l}-0.124^{* * *} \\
(0.0000)\end{array}$ & $\begin{array}{c}-0.167^{* * *} \\
(0.0000)\end{array}$ & $\begin{array}{l}-0.162^{* * *} \\
(0.0000)\end{array}$ & $\begin{array}{l}-0.169^{* * *} \\
(0.0000)\end{array}$ & $\begin{array}{l}-0.162^{* * *} \\
(0.0000)\end{array}$ & & \\
\hline $\ln R D_{t-1}$ & & & & & & $\begin{array}{c}-0.059^{* * *} \\
(0.0000)\end{array}$ & $\begin{array}{l}-0.050^{* *} \\
(0.0011)\end{array}$ \\
\hline Spell Number & $\begin{array}{c}-0.001 \\
(0.9923)\end{array}$ & $\begin{array}{c}-0.074 \\
(0.7124)\end{array}$ & $\begin{array}{c}-0.015 \\
(0.8965)\end{array}$ & $\begin{array}{c}-0.039 \\
(0.8133)\end{array}$ & $\begin{array}{c}0.013 \\
(0.9160)\end{array}$ & $\begin{array}{c}0.035 \\
(0.7343)\end{array}$ & $\begin{array}{c}0.023 \\
(0.8135)\end{array}$ \\
\hline Time & $\begin{array}{l}-0.112^{* * *} \\
(0.0011)\end{array}$ & $\begin{array}{l}-0.227^{* * *} \\
(0.0000)\end{array}$ & $\begin{array}{l}-0.164^{* * *} \\
(0.0000)\end{array}$ & $\begin{array}{l}-0.238^{* * *} \\
(0.0000)\end{array}$ & $\begin{array}{l}-0.171^{* * *} \\
(0.0000)\end{array}$ & $\begin{array}{l}-0.199^{* * *} \\
(0.0000)\end{array}$ & $\begin{array}{c}-0.129^{* * *} \\
(0.0002)\end{array}$ \\
\hline \multicolumn{8}{|l|}{ Left Censoring } \\
\hline Left Cens. & $\begin{array}{l}-0.358^{* * *} \\
(0.0004)\end{array}$ & $\begin{array}{l}-0.212^{* *} \\
(0.0292)\end{array}$ & $\begin{array}{c}-0.398^{* * *} \\
(0.0000)\end{array}$ & $\begin{array}{c}-0.162 \\
(0.1027)\end{array}$ & $\begin{array}{l}-0.355^{* * *} \\
(0.0015)\end{array}$ & $\begin{array}{l}-0.269^{* *} \\
(0.0377)\end{array}$ & $\begin{array}{c}-0.487^{* * *} \\
(0.0000)\end{array}$ \\
\hline \multicolumn{8}{|l|}{ Investments } \\
\hline IM & $\begin{array}{c}0.089 \\
(0.8500)\end{array}$ & $\begin{array}{c}1.229 \\
(0.2603)\end{array}$ & $\begin{array}{c}1.096 \\
(0.3099)\end{array}$ & & & $\begin{array}{c}1.526 \\
(0.2966)\end{array}$ & \\
\hline$\Delta \mathrm{IM}$ & & & & $\begin{array}{c}0.490 \\
(0.6850)\end{array}$ & $\begin{array}{c}0.106 \\
(0.9149)\end{array}$ & & $\begin{array}{c}0.303 \\
(0.8238)\end{array}$ \\
\hline IS & $\begin{array}{c}-25.656^{* *} \\
(0.0117)\end{array}$ & $\begin{array}{l}-21.576 \\
(0.1718)\end{array}$ & $\begin{array}{l}-23.304^{*} \\
(0.0662)\end{array}$ & & & $\begin{array}{l}-20.654 \\
(0.1722)\end{array}$ & \\
\hline$\Delta \mathrm{IS}$ & & & & $\begin{array}{l}-12.240 \\
(0.1402)\end{array}$ & $\begin{array}{l}-11.885^{*} \\
(0.0618)\end{array}$ & & $\begin{array}{c}-7.993 \\
(0.3806)\end{array}$ \\
\hline \multicolumn{8}{|l|}{ Finances } \\
\hline$C F_{t}$ & $\begin{array}{c}-0.809 \\
(0.2524)\end{array}$ & $\begin{array}{c}-0.652 \\
(0.2507)\end{array}$ & $\begin{array}{l}-0.900^{*} \\
(0.0756)\end{array}$ & $\begin{array}{c}-0.390 \\
(0.4801)\end{array}$ & $\begin{array}{c}-0.653 \\
(0.2020)\end{array}$ & & \\
\hline$C F_{t-1}$ & & & & & & $\begin{array}{c}-0.531 \\
(0.4751)\end{array}$ & $\begin{array}{c}-0.439 \\
(0.4950)\end{array}$ \\
\hline $\mathrm{D}_{\mathrm{t}}$ & $\begin{array}{c}0.158 \\
(0.2608)\end{array}$ & $\begin{array}{c}0.055 \\
(0.7898)\end{array}$ & $\begin{array}{c}0.146 \\
(0.3149)\end{array}$ & $\begin{array}{c}0.085 \\
(0.6736)\end{array}$ & $\begin{array}{c}0.176 \\
(0.3314)\end{array}$ & & \\
\hline $\mathrm{D}_{\mathrm{t}-1}$ & & & & & & $\begin{array}{c}0.254 \\
(0.2601)\end{array}$ & $\begin{array}{c}0.304 \\
(0.1969)\end{array}$ \\
\hline \multicolumn{8}{|c|}{ International Competition } \\
\hline Exp & $\begin{array}{c}0.032 \\
(0.6952)\end{array}$ & $\begin{array}{l}-0.163^{*} \\
(0.0890)\end{array}$ & $\begin{array}{l}-0.178^{* *} \\
(0.0116)\end{array}$ & $\begin{array}{l}-0.187^{*} \\
(0.0837)\end{array}$ & $\begin{array}{l}-0.192^{* *} \\
(0.0206)\end{array}$ & $\begin{array}{l}-0.217^{* *} \\
(0.0443)\end{array}$ & $\begin{array}{c}-0.240^{* * *} \\
(0.0085)\end{array}$ \\
\hline \multicolumn{8}{|c|}{ Technological Opportunities } \\
\hline HTech & $\begin{array}{c}0.022 \\
(0.9024)\end{array}$ & $\begin{array}{c}-0.240 \\
(0.4104)\end{array}$ & $\begin{array}{c}-0.169 \\
(0.4722)\end{array}$ & $\begin{array}{c}-0.410 \\
(0.2114)\end{array}$ & $\begin{array}{c}-0.318 \\
(0.2817)\end{array}$ & $\begin{array}{c}-0.413 \\
(0.2249)\end{array}$ & $\begin{array}{l}-0.460^{*} \\
(0.0895)\end{array}$ \\
\hline \multicolumn{8}{|l|}{ Market Power } \\
\hline $\mathrm{PCM}$ & $\begin{array}{c}0.562 \\
(0.3643)\end{array}$ & & & & & & \\
\hline$-\eta$ & & $\begin{array}{c}0.004 \\
(0.9719)\end{array}$ & $\begin{array}{c}0.021 \\
(0.8560)\end{array}$ & $\begin{array}{c}0.027 \\
(0.8093)\end{array}$ & $\begin{array}{c}0.042 \\
(0.7159)\end{array}$ & $\begin{array}{c}0.038 \\
(0.8030)\end{array}$ & $\begin{array}{c}0.044 \\
(0.7724)\end{array}$ \\
\hline \multicolumn{8}{|l|}{ Uncertainty } \\
\hline Bloom & & & $\begin{array}{l}-0.006^{* * *} \\
(0.0000)\end{array}$ & & $\begin{array}{l}-0.006^{* * *} \\
(0.0000)\end{array}$ & & $\begin{array}{c}-0.007^{* * *} \\
(0.0000)\end{array}$ \\
\hline $\begin{array}{l}\text { Time dummies } \\
\text { Control Variables }\end{array}$ & Yes & Yes & No & Yes & No & Yes & No \\
\hline ln Age & $\begin{array}{c}0.023 \\
(0.6221)\end{array}$ & $\begin{array}{c}-0.054 \\
(0.3702)\end{array}$ & $\begin{array}{c}-0.048 \\
(0.4638)\end{array}$ & $\begin{array}{c}-0.050 \\
(0.5117)\end{array}$ & $\begin{array}{c}-0.043 \\
(0.5562)\end{array}$ & $\begin{array}{l}-0.075 \\
(0.3001)\end{array}$ & $\begin{array}{c}-0.063 \\
(0.4065)\end{array}$ \\
\hline ln Size & $\begin{array}{c}-0.045 \\
(0.3164)\end{array}$ & $\begin{array}{c}-0.008 \\
(0.8821)\end{array}$ & $\begin{array}{c}-0.013 \\
(0.8190)\end{array}$ & $\begin{array}{c}-0.015 \\
(0.7924)\end{array}$ & $\begin{array}{c}-0.029 \\
(0.5945)\end{array}$ & $\begin{array}{l}-0.087^{*} \\
(0.0656)\end{array}$ & $\begin{array}{l}-0.107^{* *} \\
(0.0324)\end{array}$ \\
\hline Group & $\begin{array}{c}-0.033 \\
(0.7225)\end{array}$ & $\begin{array}{c}-0.010 \\
(0.9093)\end{array}$ & $\begin{array}{c}0.006 \\
(0.9381)\end{array}$ & $\begin{array}{c}-0.002 \\
(0.9851)\end{array}$ & $\begin{array}{c}0.023 \\
(0.7998)\end{array}$ & $\begin{array}{c}-0.033 \\
(0.8094)\end{array}$ & $\begin{array}{c}-0.013 \\
(0.8969)\end{array}$ \\
\hline Family & $\begin{array}{c}-0.056 \\
(0.4753)\end{array}$ & $\begin{array}{c}-0.041 \\
(0.6607)\end{array}$ & $\begin{array}{c}-0.091 \\
(0.2722)\end{array}$ & $\begin{array}{c}-0.080 \\
(0.3668)\end{array}$ & $\begin{array}{l}-0.132^{*} \\
(0.0776)\end{array}$ & $\begin{array}{c}-0.156 \\
(0.1210)\end{array}$ & $\begin{array}{l}-0.198^{* *} \\
(0.0395)\end{array}$ \\
\hline Centre & $\begin{array}{c}0.036 \\
(0.7020)\end{array}$ & $\begin{array}{c}0.141 \\
(0.1894)\end{array}$ & $\begin{array}{c}0.095 \\
(0.3570)\end{array}$ & $\begin{array}{c}0.188 \\
(0.1149)\end{array}$ & $\begin{array}{c}0.136 \\
(0.2362)\end{array}$ & $\begin{array}{l}0.269^{* *} \\
(0.0357)\end{array}$ & $\begin{array}{l}0.239^{* *} \\
(0.0433)\end{array}$ \\
\hline South & $\begin{array}{l}0.221^{* *} \\
(0.0440)\end{array}$ & $\begin{array}{l}0.294^{* * * *} \\
(0.0016)\end{array}$ & $\begin{array}{l}0.253^{* *} \\
(0.0385)\end{array}$ & $\begin{array}{l}0.334^{* * *} \\
(0.0001)\end{array}$ & $\begin{array}{l}0.290^{* *} \\
(0.0082)\end{array}$ & $\begin{array}{l}0.463^{* * *} \\
(0.0001)\end{array}$ & $\begin{array}{l}0.441^{* * *} \\
(0.0002)\end{array}$ \\
\hline Const & $\begin{array}{c}0.065 \\
(0.8237)\end{array}$ & $\begin{array}{c}0.232 \\
(0.5725)\end{array}$ & $\begin{array}{l}0.949^{* *} \\
(0.0453)\end{array}$ & $\begin{array}{c}0.237 \\
(0.6534)\end{array}$ & $\begin{array}{l}0.967^{* *} \\
(0.0382)\end{array}$ & $\begin{array}{c}-0.615 \\
(0.1748)\end{array}$ & $\begin{array}{c}0.733^{*} \\
(0.0966)\end{array}$ \\
\hline $\begin{array}{l}\text { L-Likelihood } \\
\rho\end{array}$ & $\begin{array}{c}-2122.561 \\
0.012\end{array}$ & $\begin{array}{c}-1705.980 \\
0.033\end{array}$ & $\begin{array}{c}-1718.848 \\
0.000\end{array}$ & $\begin{array}{c}-1522.887 \\
0.035\end{array}$ & $\begin{array}{c}-1535.417 \\
0.005\end{array}$ & $\begin{array}{c}-1225.291 \\
0.000\end{array}$ & $\begin{array}{c}-1237 \cdot 343 \\
0.000\end{array}$ \\
\hline$\sigma_{\rho}$ & 0.142 & 0.237 & 0.007 & 0.242 & 0.087 & 0.005 & 0.004 \\
\hline A.I.C. & 4297.122 & 3465.961 & 3477.696 & $3099 \cdot 773$ & 3110.834 & $2504 \cdot 582$ & 2514.686 \\
\hline B.I.C. & 4462.054 & $3635 \cdot 745$ & 3603.461 & 3266.830 & 3234.580 & 2667.648 & 2635.430 \\
\hline $\mathrm{N}$ & 4203 & 3977 & 3977 & 3595 & 3595 & 3101 & 3094 \\
\hline
\end{tabular}

P-values are in parenthesis. All estimations were run with the Stata command $x t c l o g \log$ and bootstrapped errors. Parameter $\rho$ represents the fraction of variance due to unobserved heterogeneity. 
Table 10: Robustness Checks for the Complementary Log-Logistic Model with Gamma-Distributed Frailty.

\begin{tabular}{|c|c|c|c|c|c|c|c|}
\hline & (1) & (2) & (3) & (4) & (5) & (6) & (7) \\
\hline \multicolumn{8}{|l|}{ Cumulativeness } \\
\hline $\ln \mathrm{RD}_{\mathrm{t}}$ & $\begin{array}{c}-0.132^{* * *} \\
(0.0000)\end{array}$ & $\begin{array}{c}-0.186^{* * *} \\
(0.0000)\end{array}$ & $\begin{array}{l}-0.172^{* * *} \\
(0.0000)\end{array}$ & $\begin{array}{l}-0.214^{* * *} \\
(0.0000)\end{array}$ & $\begin{array}{l}-0.196^{* * *} \\
(0.0000)\end{array}$ & & \\
\hline $\ln R D_{t-1}$ & & & & & & $\begin{array}{l}-0.083^{* * *} \\
(0.0004)\end{array}$ & $\begin{array}{c}-0.080^{* * *} \\
(0.0001)\end{array}$ \\
\hline Spell Number & $\begin{array}{c}0.004 \\
(0.9684)\end{array}$ & $\begin{array}{c}-0.116 \\
(0.3551)\end{array}$ & $\begin{array}{c}-0.106 \\
(0.3758)\end{array}$ & $\begin{array}{c}-0.042 \\
(0.7471)\end{array}$ & $\begin{array}{c}-0.025 \\
(0.8406)\end{array}$ & $\begin{array}{c}0.015 \\
(0.9203)\end{array}$ & $\begin{array}{c}0.083 \\
(0.5750)\end{array}$ \\
\hline Time & $\begin{array}{l}-0.094^{*} \\
(0.0797)\end{array}$ & $\begin{array}{c}-0.167^{* * * *} \\
(0.0002)\end{array}$ & $\begin{array}{c}-0.041 \\
(0.2368)\end{array}$ & $\begin{array}{c}-0.160^{* * *} \\
(0.0010)\end{array}$ & $\begin{array}{c}-0.038 \\
(0.4392)\end{array}$ & $\begin{array}{l}-0.103^{*} \\
(0.0914)\end{array}$ & $\begin{array}{c}0.058 \\
(0.3525)\end{array}$ \\
\hline \multicolumn{8}{|l|}{ Left Censoring } \\
\hline Left Cens. & $\begin{array}{l}-0.387^{* * *} \\
(0.0017)\end{array}$ & $\begin{array}{l}-0.333^{* *} \\
(0.0372)\end{array}$ & $\begin{array}{l}-0.765^{* * *} \\
(0.0000)\end{array}$ & $\begin{array}{c}-0.216 \\
(0.2134)\end{array}$ & $\begin{array}{l}-0.628^{* * *} \\
(0.0000)\end{array}$ & $\begin{array}{c}-0.261 \\
(0.2135)\end{array}$ & $\begin{array}{c}-0.716^{* * *} \\
(0.0001)\end{array}$ \\
\hline \multicolumn{8}{|l|}{ Investments } \\
\hline IM & $\begin{array}{c}0.125 \\
(0.7391)\end{array}$ & $\begin{array}{c}1.826 \\
(0.1223)\end{array}$ & $\begin{array}{c}1.407 \\
(0.2177)\end{array}$ & & & $\begin{array}{c}1.486 \\
(0.3643)\end{array}$ & \\
\hline$\Delta \mathrm{IM}$ & & & & $\begin{array}{c}-0.198 \\
(0.9037)\end{array}$ & $\begin{array}{c}-0.533 \\
(0.7289)\end{array}$ & & $\begin{array}{c}0.618 \\
(0.7080)\end{array}$ \\
\hline IS & $\begin{array}{c}-31.461^{* *} \\
(0.0332)\end{array}$ & $\begin{array}{l}-33.054^{*} \\
(0.0672)\end{array}$ & $\begin{array}{c}-37.888^{* *} \\
(0.0442)\end{array}$ & & & $\begin{array}{l}-37.727^{*} \\
(0.0881)\end{array}$ & \\
\hline$\Delta \mathrm{IS}$ & & & & $\begin{array}{c}-7.012 \\
(0.5014)\end{array}$ & $\begin{array}{c}-8.264 \\
(0.3964)\end{array}$ & & $\begin{array}{c}-0.546 \\
(0.9545)\end{array}$ \\
\hline \multicolumn{8}{|l|}{ Finances } \\
\hline$C F_{t}$ & $\begin{array}{c}-2.155^{* * *} \\
(0.0056)\end{array}$ & $\begin{array}{c}-0.853 \\
(0.2284)\end{array}$ & $\begin{array}{c}-1.083 \\
(0.1043)\end{array}$ & $\begin{array}{c}-0.775 \\
(0.2981)\end{array}$ & $\begin{array}{l}-1.070 \\
(0.1191)\end{array}$ & & \\
\hline$C F_{t-1}$ & & & & & & $\begin{array}{c}-1.592 \\
(0.1182)\end{array}$ & $\begin{array}{l}-1.671^{*} \\
(0.0621)\end{array}$ \\
\hline $\mathrm{D}_{\mathrm{t}}$ & $\begin{array}{c}0.132 \\
(0.4766)\end{array}$ & $\begin{array}{c}0.162 \\
(0.5358)\end{array}$ & $\begin{array}{c}0.268 \\
(0.2837)\end{array}$ & $\begin{array}{c}0.128 \\
(0.6487)\end{array}$ & $\begin{array}{c}0.244 \\
(0.3515)\end{array}$ & & \\
\hline$D_{t-1}$ & & & & & & $\begin{array}{c}0.508 \\
(0.1269)\end{array}$ & $\begin{array}{c}0.533^{*} \\
(0.0959)\end{array}$ \\
\hline \multicolumn{8}{|c|}{ International Competition } \\
\hline Exp & $\begin{array}{c}-0.069 \\
(0.4663)\end{array}$ & $\begin{array}{c}-0.120 \\
(0.3476)\end{array}$ & $\begin{array}{c}-0.137 \\
(0.2477)\end{array}$ & $\begin{array}{c}-0.146 \\
(0.2770)\end{array}$ & $\begin{array}{c}-0.145 \\
(0.2395)\end{array}$ & $\begin{array}{c}-0.132 \\
(0.4197)\end{array}$ & $\begin{array}{c}-0.119 \\
(0.4375)\end{array}$ \\
\hline \multicolumn{8}{|c|}{ Technological Opportunities } \\
\hline HTech & $\begin{array}{c}0.068 \\
(0.7751)\end{array}$ & $\begin{array}{c}-0.230 \\
(0.5082)\end{array}$ & $\begin{array}{c}-0.048 \\
(0.8853)\end{array}$ & $\begin{array}{c}-0.225 \\
(0.5280)\end{array}$ & $\begin{array}{c}-0.034 \\
(0.9189)\end{array}$ & $\begin{array}{c}-0.132 \\
(0.7567)\end{array}$ & $\begin{array}{c}-0.110 \\
(0.7863)\end{array}$ \\
\hline $\begin{array}{l}\text { Market Power } \\
\text { PCM }\end{array}$ & $\begin{array}{l}1.757^{* *} \\
(0.0127)\end{array}$ & & & & & & \\
\hline$-\eta$ & & $\begin{array}{l}-0.302^{*} \\
(0.0616)\end{array}$ & $\begin{array}{l}-0.255^{*} \\
(0.0893)\end{array}$ & $\begin{array}{c}-0.261 \\
(0.1344)\end{array}$ & $\begin{array}{c}-0.230 \\
(0.1499)\end{array}$ & $\begin{array}{l}-0.421^{*} \\
(0.0581)\end{array}$ & $\begin{array}{l}-0.410^{*} \\
(0.0547)\end{array}$ \\
\hline \multicolumn{8}{|l|}{ Uncertainty } \\
\hline Bloom & & & $\begin{array}{c}-0.002 \\
(0.3555)\end{array}$ & & $\begin{array}{c}-0.003 \\
(0.1974)\end{array}$ & & $\begin{array}{l}-0.005^{* *} \\
(0.0233)\end{array}$ \\
\hline $\begin{array}{l}\text { Time Dummies } \\
\text { Control Variables }\end{array}$ & Yes & Yes & No & Yes & No & Yes & No \\
\hline ln Age & $\begin{array}{c}-0.060 \\
(0.3441)\end{array}$ & $\begin{array}{c}-0.071 \\
(0.4408)\end{array}$ & $\begin{array}{c}-0.056 \\
(0.5049)\end{array}$ & $\begin{array}{c}-0.024 \\
(0.8084)\end{array}$ & $\begin{array}{c}-0.009 \\
(0.9161)\end{array}$ & $\begin{array}{c}-0.032 \\
(0.8029)\end{array}$ & $\begin{array}{c}-0.009 \\
(0.9401)\end{array}$ \\
\hline $\ln$ Size & $\begin{array}{c}0.024 \\
(0.6758)\end{array}$ & $\begin{array}{c}-0.047 \\
(0.5351)\end{array}$ & $\begin{array}{c}-0.063 \\
(0.3649)\end{array}$ & $\begin{array}{c}-0.058 \\
(0.4844)\end{array}$ & $\begin{array}{l}-0.081 \\
(0.2959)\end{array}$ & $\begin{array}{c}-0.148 \\
(0.1187)\end{array}$ & $\begin{array}{l}-0.186^{* *} \\
(0.0394)\end{array}$ \\
\hline Group & $\begin{array}{c}0.081 \\
(0.3966)\end{array}$ & $\begin{array}{c}0.025 \\
(0.8453)\end{array}$ & $\begin{array}{c}0.060 \\
(0.6185)\end{array}$ & $\begin{array}{c}0.065 \\
(0.6378)\end{array}$ & $\begin{array}{c}0.108 \\
(0.3955)\end{array}$ & $\begin{array}{c}0.037 \\
(0.8262)\end{array}$ & $\begin{array}{c}0.076 \\
(0.6363)\end{array}$ \\
\hline Family & $\begin{array}{c}-0.029 \\
(0.7562)\end{array}$ & $\begin{array}{c}-0.042 \\
(0.7366)\end{array}$ & $\begin{array}{c}-0.132 \\
(0.2531)\end{array}$ & $\begin{array}{c}-0.018 \\
(0.8908)\end{array}$ & $\begin{array}{c}-0.108 \\
(0.3704)\end{array}$ & $\begin{array}{c}0.014 \\
(0.9299)\end{array}$ & $\begin{array}{c}-0.070 \\
(0.6486)\end{array}$ \\
\hline Centre & $\begin{array}{c}0.076 \\
(0.4862)\end{array}$ & $\begin{array}{l}0.260^{*} \\
(0.0705)\end{array}$ & $\begin{array}{c}0.172 \\
(0.2060)\end{array}$ & $\begin{array}{c}0.232 \\
(0.1299)\end{array}$ & $\begin{array}{c}0.149 \\
(0.2925)\end{array}$ & $\begin{array}{l}0.447^{* *} \\
(0.0170)\end{array}$ & $\begin{array}{l}0.393^{* *} \\
(0.0284)\end{array}$ \\
\hline South & $\begin{array}{l}0.311^{* * *} \\
(0.0077)\end{array}$ & $\begin{array}{l}0.626^{* * *} \\
(0.0001)\end{array}$ & $\begin{array}{l}0.525^{* * *} \\
(0.0002)\end{array}$ & $\begin{array}{l}0.585^{* * *} \\
\text { (0.0005) }\end{array}$ & $\begin{array}{l}0.480^{* * * *} \\
(0.0015)\end{array}$ & $\begin{array}{l}0.781^{* * *} \\
(0.0002)\end{array}$ & $\begin{array}{l}0.720^{* * *} \\
(0.0003)\end{array}$ \\
\hline Const. & $\begin{array}{l}-0.743^{*} \\
(0.0531)\end{array}$ & $\begin{array}{l}-1.119^{*} \\
(0.0708)\end{array}$ & $\begin{array}{c}-0.485 \\
(0.3754)\end{array}$ & $\begin{array}{l}-1.055 \\
(0.1240)\end{array}$ & $\begin{array}{c}-0.478 \\
(0.4145)\end{array}$ & $\begin{array}{c}-2.482^{* * *} \\
(0.0031)\end{array}$ & $\begin{array}{l}-1.245^{*} \\
(0.0951)\end{array}$ \\
\hline L-Likelihood & -1630.360 & -1072.294 & -1108.750 & -997.259 & $-1027 \cdot 384$ & -800.257 & -825.080 \\
\hline$\chi^{2}$ Test & 984.419 & 1267.457 & 1220.194 & 1051.383 & 1016.068 & 850.069 & 824.526 \\
\hline P-value(u) & 0.000 & 0.000 & 0.000 & 0.000 & 0.000 & 0.000 & 0.000 \\
\hline A.I.C. & 3312.720 & 2198.587 & 2257.501 & 2048.518 & 2094.768 & 1654.513 & 1690.159 \\
\hline B.I.C. & 3477.653 & 2368.371 & 2383.267 & $2215 \cdot 575$ & 2218.514 & 1817.579 & 1810.904 \\
\hline $\mathrm{N}$ & 4203 & 3977 & 3977 & 3595 & 3595 & 3101 & 3094 \\
\hline
\end{tabular}

P-values are in parenthesis. All estimations were run with the Stata command pgmhaz8. The reported $\chi^{2}$ test checks for the presence of unobserved heterogeneity. 
Table 11: Robustness Check for the Complementary Log-Logistic Model with Mass-Points Frailty.

\begin{tabular}{|c|c|c|c|c|c|c|c|}
\hline & $(1)$ & (1a) & $(2)$ & (3) & (5) & $(6)$ & (7) \\
\hline \multicolumn{8}{|l|}{ Cumulativeness } \\
\hline $\ln R D_{t}$ & $\begin{array}{c}-0.135^{* * *} \\
(0.0000)\end{array}$ & $\begin{array}{c}-0.136^{* * *} \\
(0.0000)\end{array}$ & $\begin{array}{c}-0.172 \\
(.)\end{array}$ & $\begin{array}{c}-0.172^{* * *} \\
(0.0000)\end{array}$ & $\begin{array}{l}-0.200^{* * *} \\
(0.0000)\end{array}$ & & \\
\hline $\ln R D_{t-1}$ & & & & & & $\begin{array}{c}-0.076^{* * *} \\
(0.0000)\end{array}$ & $\begin{array}{c}-0.079^{* * *} \\
(0.0000)\end{array}$ \\
\hline Spell Number & $\begin{array}{c}0.012 \\
(0.9151)\end{array}$ & $\begin{array}{c}0.013 \\
(0.9062)\end{array}$ & $\begin{array}{c}0.056 \\
(.)\end{array}$ & $\begin{array}{c}-0.106 \\
(0.3766)\end{array}$ & $\begin{array}{c}-0.019 \\
(0.8815)\end{array}$ & $\begin{array}{c}0.038 \\
(.)\end{array}$ & $\begin{array}{c}0.067 \\
(0.6391)\end{array}$ \\
\hline Time & $\begin{array}{c}-0.083 \\
(0.2060)\end{array}$ & $\begin{array}{c}-0.084 \\
(0.1292)\end{array}$ & $\begin{array}{l}0.029^{* * *} \\
(0.0000)\end{array}$ & $\begin{array}{c}-0.041 \\
(0.2594)\end{array}$ & $\begin{array}{c}-0.029 \\
(0.4672)\end{array}$ & $\begin{array}{c}-0.010 \\
(0.8388)\end{array}$ & $\begin{array}{c}0.046 \\
(0.3606)\end{array}$ \\
\hline \multicolumn{8}{|l|}{ Left Censoring } \\
\hline Left Cens & $\begin{array}{c}-0.394^{* * *} \\
(0.0049)\end{array}$ & $\begin{array}{c}-0.388^{* * *} \\
(0.0020)\end{array}$ & $\begin{array}{c}-0.611^{* * *} \\
(0.0002)\end{array}$ & $\begin{array}{c}-0.766^{* * *} \\
(0.0000)\end{array}$ & $\begin{array}{c}-0.641^{* * *} \\
(0.0000)\end{array}$ & $\begin{array}{c}-0.349^{*} \\
(0.0800)\end{array}$ & $\begin{array}{c}-0.717^{* * *} \\
(0.0001)\end{array}$ \\
\hline \multicolumn{8}{|l|}{ Investments } \\
\hline IM & $\begin{array}{c}0.137 \\
(0.7111)\end{array}$ & $\begin{array}{c}0.146 \\
(0.6963)\end{array}$ & $\begin{array}{c}-0.115 \\
(0.9831)\end{array}$ & $\begin{array}{c}1.411 \\
(0.2170)\end{array}$ & & $\begin{array}{c}1.783 \\
(0.7094)\end{array}$ & \\
\hline$\Delta \mathrm{IM}$ & & & & & $\begin{array}{c}-0.471 \\
(0.7594)\end{array}$ & & $\begin{array}{c}0.735 \\
(0.6440)\end{array}$ \\
\hline IS & $\begin{array}{c}-33.147^{* *} \\
(0.0309)\end{array}$ & $\begin{array}{c}-33.594^{* *} \\
(0.0314)\end{array}$ & $\begin{array}{c}-21.460 \\
(.)\end{array}$ & $\begin{array}{c}-38.422^{* *} \\
(0.0427)\end{array}$ & & $\begin{array}{l}-24.651 \\
(0.3051)\end{array}$ & \\
\hline$\Delta \mathrm{IS}$ & & & & & $\begin{array}{c}-7.768 \\
(0.4296)\end{array}$ & & $\begin{array}{c}-0.801 \\
(0.9318)\end{array}$ \\
\hline \multicolumn{8}{|l|}{ Finances } \\
\hline$C F_{t}$ & $\begin{array}{c}-2.193^{* * *} \\
(0.0057)\end{array}$ & $\begin{array}{c}-2.188^{* * *} \\
(0.0058)\end{array}$ & $\begin{array}{c}-1.376 \\
(.)\end{array}$ & $\begin{array}{c}-1.084 \\
(0.1043)\end{array}$ & $\begin{array}{c}-1.053 \\
(0.1260)\end{array}$ & & \\
\hline$C F_{t-1}$ & & & & & & $\begin{array}{c}-1.993 \\
(0.1309)\end{array}$ & $\begin{array}{l}-1.670^{*} \\
(0.0528)\end{array}$ \\
\hline $\mathrm{D}_{\mathrm{t}}$ & $\begin{array}{c}0.137 \\
(0.4673)\end{array}$ & $\begin{array}{c}0.143 \\
(0.4536)\end{array}$ & $\begin{array}{c}-0.552 \\
(.)\end{array}$ & $\begin{array}{c}0.268 \\
(0.2835)\end{array}$ & $\begin{array}{c}0.251 \\
(0.3439)\end{array}$ & & \\
\hline $\mathrm{D}_{\mathrm{t}-1}$ & & & & & & $\begin{array}{c}0.495 \\
(.)\end{array}$ & $\begin{array}{c}0.527^{*} \\
(0.0891)\end{array}$ \\
\hline \multicolumn{8}{|c|}{ International Competition } \\
\hline Exp & $\begin{array}{c}-0.072 \\
(0.4545)\end{array}$ & $\begin{array}{c}-0.072 \\
(0.4539)\end{array}$ & $\begin{array}{c}-0.209 \\
(.)\end{array}$ & $\begin{array}{c}-0.137 \\
(0.2486)\end{array}$ & $\begin{array}{c}-0.143 \\
(0.2514)\end{array}$ & $\begin{array}{c}-0.221 \\
(0.2325)\end{array}$ & $\begin{array}{c}-0.109 \\
(0.4717)\end{array}$ \\
\hline \multicolumn{8}{|c|}{ Technological Opportunities } \\
\hline HTech & $\begin{array}{c}0.058 \\
(0.8143)\end{array}$ & $\begin{array}{c}0.063 \\
(0.7969)\end{array}$ & $\begin{array}{c}-0.261 \\
(0.5798)\end{array}$ & $\begin{array}{c}-0.047 \\
(0.8870)\end{array}$ & $\begin{array}{c}-0.034 \\
(0.9198)\end{array}$ & $\begin{array}{c}-0.403 \\
(0.4946)\end{array}$ & $\begin{array}{c}-0.112 \\
(0.7787)\end{array}$ \\
\hline \multicolumn{8}{|l|}{ Market Power } \\
\hline $\mathrm{PCM}$ & $\begin{array}{c}1.793^{*} \\
(0.0135)\end{array}$ & $\begin{array}{c}1.786^{*} \\
(0.0132)\end{array}$ & & & & & \\
\hline$-\eta$ & & & $\begin{array}{c}-0.515 \\
(.)\end{array}$ & $\begin{array}{l}-0.255^{*} \\
(0.0898)\end{array}$ & $\begin{array}{c}-0.229 \\
(0.1590)\end{array}$ & $\begin{array}{c}-0.492 \\
(.)\end{array}$ & $\begin{array}{l}-0.404^{* *} \\
(0.0464)\end{array}$ \\
\hline \multicolumn{8}{|l|}{ Uncertainty } \\
\hline Bloom & & & & $\begin{array}{c}-0.002 \\
(0.3557)\end{array}$ & $\begin{array}{c}-0.002 \\
(0.2145)\end{array}$ & & $\begin{array}{l}-0.005^{* *} \\
(0.0248)\end{array}$ \\
\hline $\begin{array}{l}\text { Time Dummies } \\
\text { Control Variables }\end{array}$ & Yes & Yes & Yes & No & No & Yes & No \\
\hline ln Age & $\begin{array}{c}-0.062 \\
(0.3642)\end{array}$ & $\begin{array}{c}-0.059 \\
(0.3647)\end{array}$ & $\begin{array}{c}-0.082 \\
(.)\end{array}$ & $\begin{array}{c}-0.056 \\
(0.5044)\end{array}$ & $\begin{array}{l}-0.012 \\
(0.8937)\end{array}$ & $\begin{array}{c}-0.028 \\
(0.3210)\end{array}$ & $\begin{array}{c}-0.012 \\
(0.9173)\end{array}$ \\
\hline $\ln$ Size & $\begin{array}{c}0.022 \\
(0.7049)\end{array}$ & $\begin{array}{c}0.021 \\
(0.7178)\end{array}$ & $\begin{array}{c}-0.559 \\
(.)\end{array}$ & $\begin{array}{c}-0.063 \\
(0.3661)\end{array}$ & $\begin{array}{c}-0.090 \\
(0.2441)\end{array}$ & $\begin{array}{c}-0.166 \\
(.)\end{array}$ & $\begin{array}{l}-0.177^{* *} \\
(0.0380)\end{array}$ \\
\hline Group & $\begin{array}{c}0.085 \\
(0.3958)\end{array}$ & $\begin{array}{c}0.083 \\
(0.3942)\end{array}$ & $\begin{array}{c}0.398 \\
(.)\end{array}$ & $\begin{array}{c}0.061 \\
(0.6174)\end{array}$ & $\begin{array}{c}0.116 \\
(0.3744)\end{array}$ & $\begin{array}{c}0.088 \\
(0.5961)\end{array}$ & $\begin{array}{c}0.060 \\
(0.7048)\end{array}$ \\
\hline Family & $\begin{array}{c}-0.028 \\
(0.7734)\end{array}$ & $\begin{array}{c}-0.026 \\
(0.7927)\end{array}$ & $\begin{array}{l}0.174 \\
(.)\end{array}$ & $\begin{array}{c}-0.132 \\
(0.2537)\end{array}$ & $\begin{array}{c}-0.120 \\
(0.3338)\end{array}$ & $\begin{array}{c}0.014 \\
(0.9456)\end{array}$ & $\begin{array}{c}-0.080 \\
(0.5901)\end{array}$ \\
\hline Centre & $\begin{array}{c}0.085 \\
(0.4801)\end{array}$ & $\begin{array}{c}0.090 \\
(0.4243)\end{array}$ & $\begin{array}{l}-0.564^{* *} \\
(0.0171)\end{array}$ & $\begin{array}{c}0.172 \\
(0.2066)\end{array}$ & $\begin{array}{c}0.148 \\
(0.3006)\end{array}$ & $\begin{array}{l}0.586^{* * *} \\
(0.0018)\end{array}$ & $\begin{array}{l}0.399^{* *} \\
(0.0219)\end{array}$ \\
\hline South & $\begin{array}{l}0.321^{* *} \\
(0.0135)\end{array}$ & $\begin{array}{l}0.315^{* * *} \\
(0.0082)\end{array}$ & $\begin{array}{c}0.821 \\
(.)\end{array}$ & $\begin{array}{l}0.525^{* * *} \\
(0.0002)\end{array}$ & $\begin{array}{l}0.496^{* * *} \\
\text { (o.0010) }\end{array}$ & $\begin{array}{c}0.951 \\
(.)\end{array}$ & $\begin{array}{l}0.709^{* * *} \\
\text { (0.0001) }\end{array}$ \\
\hline Const. & $\begin{array}{c}-0.888 \\
(0.1071)\end{array}$ & $\begin{array}{c}-0.716 \\
(0.3561)\end{array}$ & $\begin{array}{c}-1.743 \\
(.)\end{array}$ & $\begin{array}{c}-2.371^{* * *} \\
(0.0000)\end{array}$ & $\begin{array}{c}-7.089 \\
(0.8682)\end{array}$ & $\begin{array}{c}-3.686 \\
(.)\end{array}$ & $\begin{array}{c}-7.526 \\
(0.7505)\end{array}$ \\
\hline L-Likelihood & -1630.210 & -1630.184 & $-1099 \cdot 506$ & -1108.750 & -1027.215 & -798.423 & -824.823 \\
\hline $\mathrm{m} 2$ & 1.660 & 2.555 & 4.240 & 1.890 & 6.726 & 3.091 & 6.458 \\
\hline P-value (m2) & $(0.7062)$ & $(0.2568)$ & $()$. & $()$. & $(0.8749)$ & $()$. & $(0.7848)$ \\
\hline A.I.C. & 3314.420 & 3316.368 & 2223.012 & $2257 \cdot 500$ & 2096.430 & 1636.846 & 1691.646 \\
\hline B.I.C. & 3485.696 & 3493.987 & 2298.471 & 2383.266 & 2226.363 & 1757.636 & 1818.427 \\
\hline $\mathrm{N}$ & 4203 & 4203 & 3977 & 3977 & 3595 & 3101 & 3094 \\
\hline
\end{tabular}

P-values are in parenthesis. All estimations were run with the Stata command hshaz. $\mathrm{m} 2$ represents the second mass points. If $\mathrm{m} 2$ is significant, there is unobserved heterogeneity. Column (1a) reports estimates for the assumption of three mass points: $\mathrm{m} 3$ is non-significant (p-value is 0.8252$)$, and estimates are consistent with the two-mass-points specification. Model (4) is not reported because of convergence problems. 
Table 12: Robustness Checks for the Random Effects Probit Model with Normally-Distributed Frailty.

\begin{tabular}{|c|c|c|c|c|c|c|c|}
\hline & (1) & (2) & (3) & (4) & (5) & (6) & (7) \\
\hline $\begin{array}{l}\text { Cumulativeness } \\
\ln \mathrm{RD}_{\mathrm{t}}\end{array}$ & $\begin{array}{l}-0.037^{* *} \\
(0.0198)\end{array}$ & $\begin{array}{c}-0.089^{* * *} \\
(0.0000)\end{array}$ & $\begin{array}{c}-0.079^{* * *} \\
(0.0011)\end{array}$ & $\begin{array}{c}-0.081^{* * *} \\
(0.0001)\end{array}$ & $\begin{array}{l}-0.074^{* * *} \\
(0.0001)\end{array}$ & & \\
\hline $\ln R D_{t-1}$ & & & & & & $\begin{array}{l}-0.026^{* *} \\
(0.0246)\end{array}$ & $\begin{array}{c}-0.017 \\
(0.1489)\end{array}$ \\
\hline Spell Number & $\begin{array}{c}-0.106 \\
(0.3580)\end{array}$ & $\begin{array}{c}-0.226 \\
(0.1946)\end{array}$ & $\begin{array}{c}-0.096 \\
(0.4450)\end{array}$ & $\begin{array}{c}-0.148 \\
(0.1970)\end{array}$ & $\begin{array}{c}-0.076 \\
(0.4733)\end{array}$ & $\begin{array}{c}-0.011 \\
(0.8820)\end{array}$ & $\begin{array}{c}-0.015 \\
(0.8483)\end{array}$ \\
\hline Time & $\begin{array}{c}-0.050^{*} \\
(0.0977)\end{array}$ & $\begin{array}{c}-0.117^{* * *} \\
(0.0001)\end{array}$ & $\begin{array}{l}-0.079^{* * *} \\
(0.0026)\end{array}$ & $\begin{array}{c}-0.132^{* * *} \\
(0.0000)\end{array}$ & $\begin{array}{c}-0.082^{* * *} \\
(0.0004)\end{array}$ & $\begin{array}{l}-0.122^{* * *} \\
(0.0000)\end{array}$ & $\begin{array}{l}-0.067^{* * *} \\
(0.0012)\end{array}$ \\
\hline $\begin{array}{l}\text { Left Censoring } \\
\text { Left Cens. } \\
\text { Investments }\end{array}$ & $\begin{array}{c}-0.267^{* * *} \\
(0.0001)\end{array}$ & $\begin{array}{c}-0.171^{* * *} \\
(0.0067)\end{array}$ & $\begin{array}{l}-0.294^{* * *} \\
(0.0001)\end{array}$ & $\begin{array}{l}-0.147^{* *} \\
(0.0143)\end{array}$ & $\begin{array}{c}-0.278^{* * *} \\
(0.0000)\end{array}$ & $\begin{array}{l}-0.167^{* *} \\
(0.0302)\end{array}$ & $\begin{array}{c}-0.319^{* * *} \\
(0.0001)\end{array}$ \\
\hline IM & $\begin{array}{c}0.225 \\
(0.5353)\end{array}$ & $\begin{array}{c}0.437 \\
(0.6812)\end{array}$ & $\begin{array}{c}0.346 \\
\text { (o.6961) }\end{array}$ & & & $\begin{array}{c}1.014 \\
(0.2664)\end{array}$ & \\
\hline$\Delta \mathrm{IM}$ & & & & $\begin{array}{c}0.469 \\
(0.5150)\end{array}$ & $\begin{array}{c}0.138 \\
(0.8044)\end{array}$ & & $\begin{array}{c}0.091 \\
(0.8803)\end{array}$ \\
\hline IS & $\begin{array}{c}-16.407^{* *} \\
(0.0363)\end{array}$ & $\begin{array}{c}-9.407 \\
(0.1745)\end{array}$ & $\begin{array}{c}-8.892 \\
(0.2883)\end{array}$ & & & $\begin{array}{l}-10.020 \\
(0.2648)\end{array}$ & \\
\hline$\Delta \mathrm{IS}$ & & & & $\begin{array}{c}-11.369^{*} \\
(0.0853)\end{array}$ & $\begin{array}{l}-11.332^{*} \\
(0.0663)\end{array}$ & & $\begin{array}{c}-13.590^{* *} \\
(0.0337)\end{array}$ \\
\hline \multicolumn{8}{|l|}{ Finances } \\
\hline$C F_{t}$ & $\begin{array}{c}-0.202 \\
(0.7222)\end{array}$ & $\begin{array}{c}-0.364 \\
(0.4519)\end{array}$ & $\begin{array}{c}-0.592 \\
(0.0851)\end{array}$ & $\begin{array}{c}-0.295 \\
(0.4736)\end{array}$ & $\begin{array}{c}-0.521 \\
(0.3647)\end{array}$ & & \\
\hline$C F_{t-1}$ & & & & & & $\begin{array}{c}-0.284 \\
(0.6206)\end{array}$ & $\begin{array}{c}-0.278 \\
(0.6219)\end{array}$ \\
\hline $\mathrm{D}_{\mathrm{t}}$ & $\begin{array}{c}-0.280 \\
(0.1284)\end{array}$ & $\begin{array}{c}-0.312 \\
(0.1844)\end{array}$ & $\begin{array}{c}-0.163 \\
(0.4340)\end{array}$ & $\begin{array}{l}-0.383^{*} \\
(0.0908)\end{array}$ & $\begin{array}{c}-0.231 \\
(0.4213)\end{array}$ & & \\
\hline$D_{t-1}$ & & & & & & $\begin{array}{c}0.117 \\
(0.6916)\end{array}$ & $\begin{array}{c}0.134 \\
(0.5567)\end{array}$ \\
\hline \multicolumn{8}{|c|}{ International Competition } \\
\hline Exp & $\begin{array}{c}0.027 \\
(0.5887)\end{array}$ & $\begin{array}{l}-0.111^{*} \\
(0.0924)\end{array}$ & $\begin{array}{l}-0.114^{* *} \\
(0.0306)\end{array}$ & $\begin{array}{l}-0.122^{*} \\
(0.0852)\end{array}$ & $\begin{array}{l}-0.120^{*} \\
(0.0655)\end{array}$ & $\begin{array}{l}-0.144^{*} \\
(0.0683)\end{array}$ & $\begin{array}{l}-0.147^{* *} \\
(0.0186)\end{array}$ \\
\hline \multicolumn{8}{|c|}{ Technological Opportunities } \\
\hline $\begin{array}{l}\text { HTech } \\
\text { Market Power }\end{array}$ & $\begin{array}{c}0.050 \\
(0.6903)\end{array}$ & $\begin{array}{c}-0.149 \\
(0.4403)\end{array}$ & $\begin{array}{c}-0.089 \\
(0.5909)\end{array}$ & $\begin{array}{c}-0.194 \\
(0.3555)\end{array}$ & $\begin{array}{c}-0.106 \\
(0.6157)\end{array}$ & $\begin{array}{c}-0.228 \\
(0.1805)\end{array}$ & $\begin{array}{c}-0.168 \\
(0.4403)\end{array}$ \\
\hline PCM & $\begin{array}{c}0.271 \\
(0.6647)\end{array}$ & & & & & & \\
\hline$-\eta$ & & $\begin{array}{c}0.013 \\
(0.8681)\end{array}$ & $\begin{array}{c}0.020 \\
(0.8086)\end{array}$ & $\begin{array}{c}0.034 \\
(0.6884)\end{array}$ & $\begin{array}{c}0.036 \\
(0.6591)\end{array}$ & $\begin{array}{c}0.027 \\
(0.7359)\end{array}$ & $\begin{array}{c}0.035 \\
(0.6527)\end{array}$ \\
\hline \multicolumn{8}{|l|}{ Uncertainty } \\
\hline Bloom & & & $\begin{array}{l}-0.004^{* * *} \\
(0.0003)\end{array}$ & & $\begin{array}{l}-0.004^{* * *} \\
(0.0000)\end{array}$ & & $\begin{array}{c}-0.005^{* * *} \\
(0.0000)\end{array}$ \\
\hline $\begin{array}{l}\text { Time Dummies } \\
\text { Control Variables }\end{array}$ & Yes & Yes & No & Yes & No & Yes & No \\
\hline ln Age & $\begin{array}{c}-0.017 \\
(0.6682)\end{array}$ & $\begin{array}{c}-0.073 \\
(0.1379)\end{array}$ & $\begin{array}{c}-0.064 \\
(0.2347)\end{array}$ & $\begin{array}{c}-0.071 \\
(0.1568)\end{array}$ & $\begin{array}{c}-0.067 \\
(0.1788)\end{array}$ & $\begin{array}{l}-0.080 \\
(0.1025)\end{array}$ & $\begin{array}{c}-0.075 \\
(0.1593)\end{array}$ \\
\hline $\ln$ Size & $\begin{array}{c}-0.029 \\
(0.4479)\end{array}$ & $\begin{array}{c}-0.001 \\
(0.9865)\end{array}$ & $\begin{array}{c}-0.009 \\
(0.8259)\end{array}$ & $\begin{array}{c}-0.008 \\
(0.8593)\end{array}$ & $\begin{array}{c}-0.020 \\
(0.5869)\end{array}$ & $\begin{array}{c}-0.036 \\
(0.2182)\end{array}$ & $\begin{array}{c}-0.051 \\
(0.1622)\end{array}$ \\
\hline Group & $\begin{array}{c}0.003 \\
(0.9623)\end{array}$ & $\begin{array}{c}0.026 \\
(0.6748)\end{array}$ & $\begin{array}{c}0.033 \\
(0.5513)\end{array}$ & $\begin{array}{c}0.040 \\
(0.6085)\end{array}$ & $\begin{array}{c}0.050 \\
(0.3931)\end{array}$ & $\begin{array}{c}0.012 \\
(0.8202)\end{array}$ & $\begin{array}{c}0.025 \\
(0.7646)\end{array}$ \\
\hline Family & $\begin{array}{l}-0.060 \\
(0.2600)\end{array}$ & $\begin{array}{c}-0.042 \\
(0.5202)\end{array}$ & $\begin{array}{c}-0.071 \\
(0.1892)\end{array}$ & $\begin{array}{c}-0.067 \\
(0.3295)\end{array}$ & $\begin{array}{l}-0.099^{* *} \\
(0.0381)\end{array}$ & $\begin{array}{c}-0.097 \\
(0.1262)\end{array}$ & $\begin{array}{l}-0.129^{*} \\
(0.0535)\end{array}$ \\
\hline Centre & $\begin{array}{c}0.040 \\
(0.5768)\end{array}$ & $\begin{array}{c}0.114 \\
(0.1971)\end{array}$ & $\begin{array}{c}0.101 \\
(0.1923)\end{array}$ & $\begin{array}{c}0.134^{*} \\
(0.0738)\end{array}$ & $\begin{array}{c}0.119 \\
(0.1328)\end{array}$ & $\begin{array}{l}0.189^{* *} \\
(0.0265)\end{array}$ & $\begin{array}{l}0.183^{* *} \\
(0.0113)\end{array}$ \\
\hline South & $\begin{array}{l}0.159^{* *} \\
(0.0274)\end{array}$ & $\begin{array}{l}0.231^{* * *} \\
(0.0030)\end{array}$ & $\begin{array}{l}0.212^{* * *} \\
(0.0010)\end{array}$ & $\begin{array}{l}0.240^{* * *} \\
(0.0048)\end{array}$ & $\begin{array}{l}0.227^{* * *} \\
(0.0038)\end{array}$ & $\begin{array}{l}0.307^{* * *} \\
(0.0000)\end{array}$ & $\begin{array}{l}0.302^{* * *} \\
(0.0016)\end{array}$ \\
\hline \multicolumn{8}{|c|}{ Mean of Continuous Explanatory Variables ${ }^{\dagger}$} \\
\hline $\ln \mathrm{RD}_{\mathrm{t}}$ & $\begin{array}{c}-0.078^{* * *} \\
(0.0000)\end{array}$ & $\begin{array}{l}-0.052^{* * *} \\
(0.0006)\end{array}$ & $\begin{array}{c}-0.048^{* * *} \\
(0.0000)\end{array}$ & $\begin{array}{l}-0.054^{* * *} \\
(0.0000)\end{array}$ & $\begin{array}{c}-0.052^{* * *} \\
(0.0001)\end{array}$ & $\begin{array}{c}-0.044^{* * *} \\
(0.0036)\end{array}$ & $\begin{array}{c}-0.048^{* * *} \\
(0.0032)\end{array}$ \\
\hline$D_{t}$ & $\begin{array}{l}0.645^{* *} \\
(0.0145)\end{array}$ & $\begin{array}{l}0.619^{* *} \\
(0.0306)\end{array}$ & $\begin{array}{l}0.454^{*} \\
(0.0638)\end{array}$ & $\begin{array}{l}0.765^{* *} \\
(0.0121)\end{array}$ & $\begin{array}{l}0.610^{* *} \\
(0.0498)\end{array}$ & $\begin{array}{c}0.140 \\
(0.6862)\end{array}$ & $\begin{array}{c}0.164 \\
(0.5979)\end{array}$ \\
\hline Const. & $\begin{array}{c}0.413 \\
(0.1497)\end{array}$ & $\begin{array}{l}0.568^{*} \\
(0.0952)\end{array}$ & $\begin{array}{l}0.951^{* * *} \\
(0.0058)\end{array}$ & $\begin{array}{c}0.510 \\
(0.1484)\end{array}$ & $\begin{array}{l}0.954^{* * *} \\
(0.0020)\end{array}$ & $\begin{array}{c}-0.123 \\
(0.7021)\end{array}$ & $\begin{array}{l}0.789^{* * *} \\
(0.0082)\end{array}$ \\
\hline L-Likelihood & -2100.921 & -1693.954 & -1707.008 & -1508.222 & -1520.811 & -1216.427 & $-1225 \cdot 562$ \\
\hline$\rho$ & 0.067 & 0.119 & 0.034 & 0.082 & 0.036 & 0.000 & 0.000 \\
\hline$\sigma_{\rho}$ & 0.267 & 0.367 & 0.189 & 0.298 & 0.194 & 0.002 & 0.002 \\
\hline A.I.C. & 4265.841 & 3451.908 & 3464.016 & 3080.445 & 3091.621 & 2496.854 & 2501.124 \\
\hline B.I.C. & 4468.835 & 3653.133 & 3621.223 & 3278.438 & 3246.304 & 2690.118 & 2652.054 \\
\hline $\mathrm{N}$ & 4203 & 3977 & 3977 & 3595 & 3595 & 3101 & 3094 \\
\hline
\end{tabular}

P-values are in parenthesis. All estimations were run with the Stata command $x$ tprobit. Parameter $\rho$ represents the fraction of variance due to unobserved heterogeneity.

$(\dagger)$ We only report significant means. 


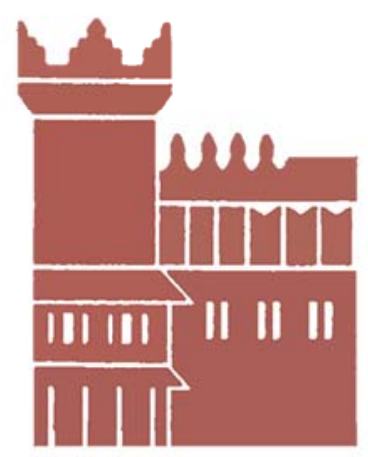

Alma Mater Studiorum - Università di Bologna DEPARTMENT OF ECONOMICS

Strada Maggiore 45

40125 Bologna - Italy

Tel. +39051 2092604

Fax +390512092664

http://www.dse.unibo.it 